INTER NATIONAL MONETARY FUND
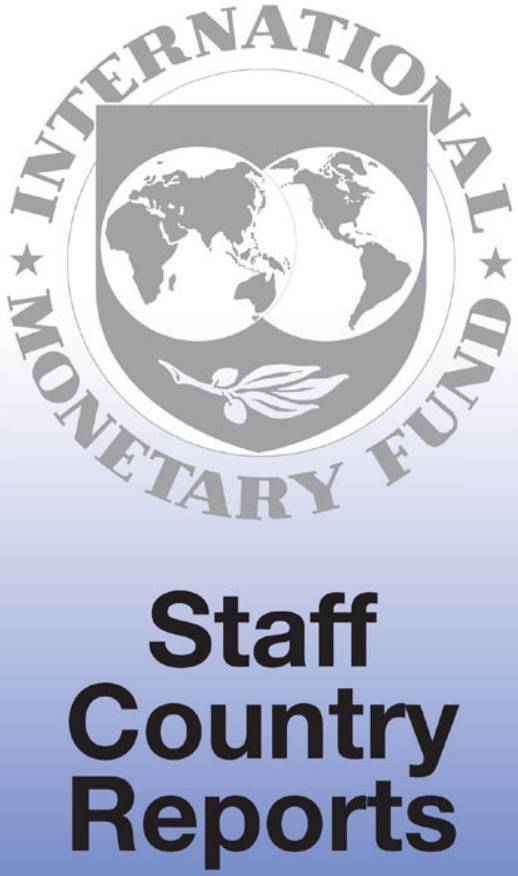


\section{Iceland: Ex Post Evaluation of Exceptional Access Under the 2008 Stand-by Arrangement}

This ex post evaluation of exceptional access under the 2008 stand-by arrangement on Iceland was prepared by a staff team of the International Monetary Fund as background documentation for the periodic consultation with the member country. It is based on the information available at the time it was completed on March 9, 2012. The views expressed in this document are those of the staff team and do not necessarily reflect the views of the government of Iceland or the Executive Board of the IMF.

The policy of publication of staff reports and other documents by the IMF allows for the deletion of market-sensitive information.

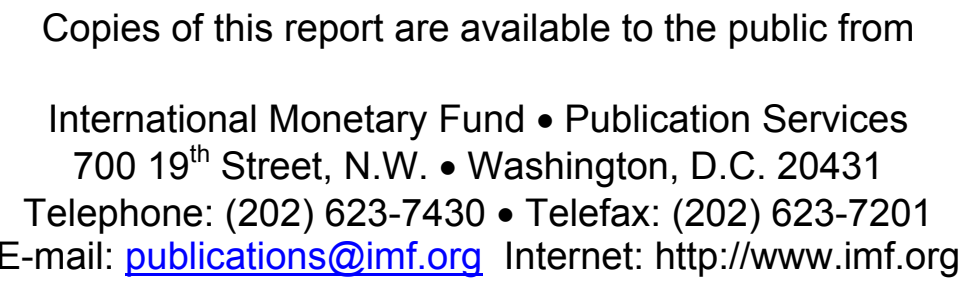

Price: $\$ 18.00$ a copy

\section{International Monetary Fund Washington, D.C.}




\section{INTERNATIONAL MONETARY FUND}

\section{ICELAND}

\section{Ex Post Evaluation of Exceptional Access Under the 2008 Stand-By Arrangement}

Prepared by an Interdepartmental Staff Team ${ }^{1}$

Approved by the European and Strategy, Policy, and Review Departments

March 23, 2012

\section{CONTENTS}

PAGE

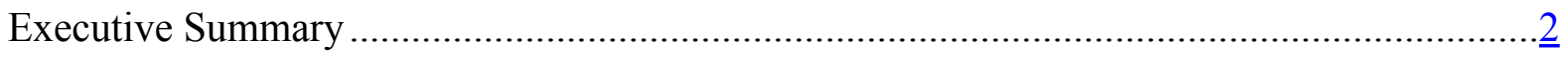

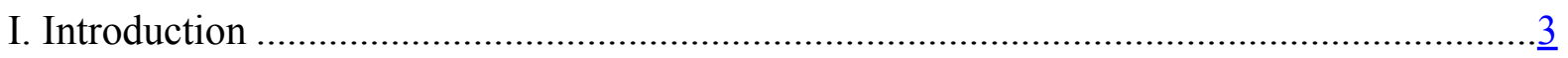

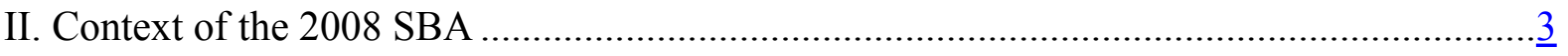

III. Key Aspects of Program Design and Exceptional Access................................................ $\frac{5}{5}$

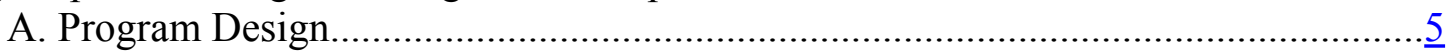

B. Financing and Adjustment Mix......................................................................

C. Justification of Exceptional Access...................................................................

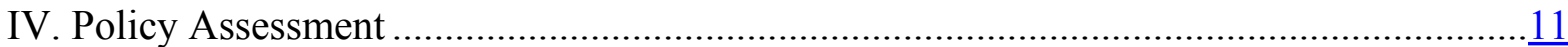

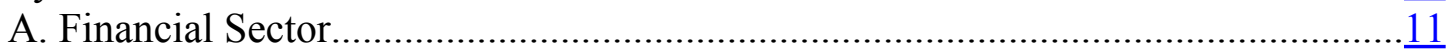

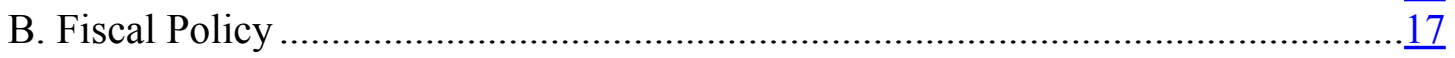

C. Monetary Policy and Capital Controls ....................................................................

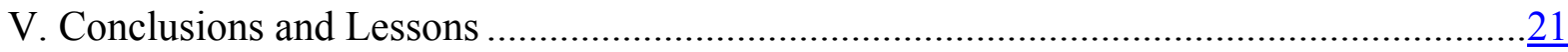

Appendix

1. Comments and Views Expressed by Icelandic Officials and Stakeholders..........................23

Tables

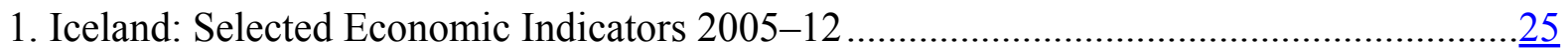

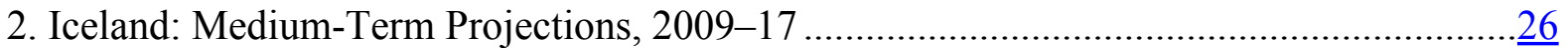

3. Iceland: Quantitative Performance Criteria and Indicative Targets ....................................27

Figures

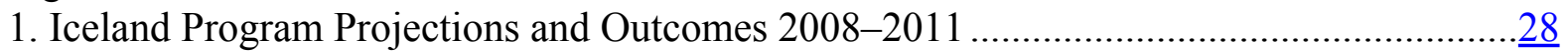

2. Loan Portfolio Restructuring: An Accelerating Process in 2011 .........................................

3. Monetary Policy Operations and Liquidity Management................................................. $\frac{30}{31}$

4. Iceland: Price and Exchange Rate Developments ........................................................

5. Iceland: Capital Control Liberalization Challenges.........................................................

\section{Boxes}

1. Icesave: Background and Implications for Financing Assurances …….............................

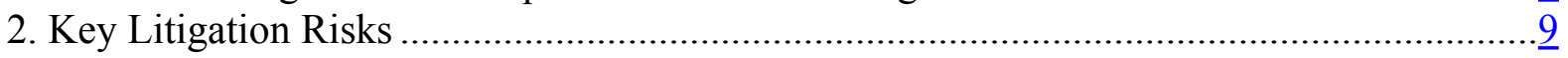

\footnotetext{
${ }^{1}$ The team comprised Emil Stavrev (head, RES), Alessandro Giustiniani (MCM), Wojciech Maliszewski (EUR), Kyung-Seol Min (FAD), Michael Tharkur (SPR), and Hui Tong (RES).
} 


\section{EXECUTIVE SUMMARY}

In the wake of the global financial crisis in late 2008, Iceland experienced a deep financial and economic crisis of its own. Given their high leverage, Icelandic banks, which were relying on wholesale funding, were cut off from financing, and a brief attempt to nationalize one of them revealed the severe problems facing the banking system which contributed to a downgrade of the sovereign. Within a short period of time, the three largest banks (Landsbanki, Glitnir and Kaupthing) collapsed. Confidence evaporated, the currency depreciated sharply and the exchange rate market ceased to operate, while other assets prices were in freefall. During 2009-10, real GDP and domestic demand declined cumulatively by a staggering $10^{1 / 2}$ and 23 percent, respectively.

As part of efforts to mitigate the crisis, Iceland received an exceptional access support from the IMF and financial assistance from bilateral creditors to cushion the economy. Following the extraordinarily large banking crisis, the Fund approved a front-loaded, 24-month Stand-By Arrangement financing of SDR 1.4 billion (equivalent to 1,190 percent of quota). The other official creditors, Denmark, Finland, Norway, Sweden, Poland, and the Faroe Island provided financial assurances, amounting to $\$ 23 / 4$ billion.

The program struck an appropriate balance between short- and medium-term objectives through flexible design, managing well the high risks faced. Deviating from orthodoxy, capital controls were introduced to stabilize the currency. Fiscal policy—initially accommodative, aimed at cushioning the economy—switched gears to consolidation to put public finances on a sustainable path. Crisis-related costs posed major risks to the program but were mitigated by the authorities' commitment and subsequent actions to limit the absorption of bank restructuring costs by public finances. Fiscal solvency concerns were addressed by setting performance criteria on the pace of public debt accumulation and on the central government's fiscal balance.

The program was successfully completed, although with some delays, owing to strong ownership. Program reviews were initially delayed due to elections in early 2009 and the formation of a new government and after that as a result of the need to secure financing assurances from bilateral creditors. Nevertheless, supported by a broad consensus within Iceland on key program goals as well as strong ownership (notably on fiscal), the program was successfully completed, meeting its key objectives. The exchange rate has been stabilized, much has been achieved in putting public finances on a sustainable path, and significant progress has been made in restructuring the banking system.

However, Iceland continues to face large risks in key areas which require further policy efforts. On fiscal front, public debt remains large, calling for continued consolidation efforts to ensure that fiscal sustainability is secured. On capital account liberalization, lifting controls is a key medium-term challenge. While keeping them for too long could prolong distortions, too quick a pace of liberalization could lead to depletion of reserves and disorderly depreciation of the currency, destabilizing the financial system. On financial sector, the still large nonperforming loans have to be further reduced through private sector debt restructuring. On financial supervision, the remaining supervisory gaps need to be addressed, in line with the action plan being prepared by the FME.

The experience with the program provided four key lessons: (i) strong ownership of the program is critical for its success; (ii) the social impact can be eased in the face of fiscal consolidation following a severe crisis by cutting expenditures without compromising welfare benefits, while introducing a more progressive tax system and improving efficiency; (iii) bank restructuring approach allowing creditors to take upside gains but also bear part of the initial costs helped limit the absorption of private sector losses by public sector; and (iv) after all other policy options are exhausted, capital controls could be used on a temporary basis in crisis cases such as Iceland, where capital controls have helped prevent disorderly deleveraging and stabilize the economy. 


\section{INTRODUCTION}

1. The Fund approved a 24-month exceptional access Stand-By Arrangement (SBA) for Iceland in November 2008, in the context of an unprecedented financial crisis. ${ }^{2}$ The size of Fund financing was SDR 1.4 billion (equivalent to 1,190 percent of quota). The approval of the SBA followed an extraordinarily large banking crisis in which three of Iceland's largest banks - representing 85 percent of the banking system and nearly 900 percent of GDPcollapsed within one week in October 2008. The banking crisis, reflecting poor asset quality and bubbles, a worsening of global credit conditions, intensifying financial disruptions and dislocation, major equity market sell-offs, and fueled by a sudden stop in capital inflows, resulted in a sharp decline in asset prices, a near free fall of the króna, and a deep recession.

\section{Supported by strong ownership, the program was completed successfully, albeit} with some delays due to initial political uncertainty. The first program review was delayed somewhat, following the collapse of the government in early 2009 and the formation of a new government. Later on there were some additional delays because of the need for ensuring financing assurances. However, supported by strong ownership, the program met its key objectives. Specifically, the exchange rate has been stabilized, Iceland's public finances have been put on a sustainable path, significant progress has been made in fixing the banking system, and private sector debt restructuring is advancing.

\section{This report assesses the effectiveness of the 2008 SBA for Iceland. ${ }^{3}$ Fund policy} requires an ex-post evaluation (EPE) of General Resources Account supported programs with exceptional access within a year after the end of the arrangement. ${ }^{4}$ This EPE report is structured as follows. Section II discusses the context of the 2008 SBA. Section III discusses some key aspects of the program, including its design, financing and adjustment mix, as well as justification for exceptional access. Section IV provides an assessment of key policies under the program, namely, financial sector, fiscal, and monetary policy and capital controls. Section V presents conclusions and key lessons.

\section{CONTEXT OF THE 2008 SBA}

4. The banking system rapidly grew out of proportion, expanding to nearly tenfold of Iceland's GDP by 2007, attending risks of a looming crisis. Following the privatization and liberalization of the banking system in 2003, the three largest banks (Landsbanki, Glitnir and

\footnotetext{
${ }^{2}$ Bilateral creditors also provided substantial financial support, with the Nordic countries (Denmark, Finland, Norway, and Sweden), contributing $\$ 2 \frac{1}{2}$ billion, Poland $\$ 200$ million, and Faroe Islands $\$ 50$ million.

${ }^{3}$ In line with Fund procedures, this report was prepared by an interdepartmental staff team, primarily on the basis of documents and data available at the time it was completed on March 9, 2012. The team is grateful for discussions with present and former officials in Iceland and representatives of the social partners and academics held during a visit in Reykjavik on December 13-16, 2012 to present the findings of the EPE as well as for discussions with present and former Fund mission chiefs and other Fund staff who were involved in the 2008 SBA. A summary of the authorities' views about the key findings of the EPE are presented in Appendix I.
}

${ }^{4}$ See Ex-Post Evaluations of Exceptional Access Arrangements Revised Guidance Note (2/25/10). 
Kaupthing) grew rapidly, both in Iceland and abroad. With easy access to international capital markets, also reflecting the European passport, banks expanded abroad through direct acquisitions as well as financing the expansion of international companies and Icelandic multinationals. Domestically, the rapid increase in lending fuelled bubbles in all asset classes, particularly the stock market and real estate. Inflated asset prices and non-transparent crossfinancing and related party lending between banks and holding companies helped mask poor asset quality and facilitated the financing of credit expansion by borrowing abroad, increasing vulnerability.

5. Iceland's economy expanded strongly during 2004-07, driven by domestic demand fed by capital inflows, reflected by growing imbalances. Real GDP expanded by 28 percent (cumulative) during 2003-07, driven by private consumption and large investments in powerintensive industries (Table 1). The spending boom was underpinned by strong growth of disposable income, easy credit, rapid increase in housing and equity wealth, and low unemployment. Warning signs were, however, evident. External imbalances ballooned, with the current account deficit exceeding 15 percent of GDP in each year over 2004-07, as the króna appreciated significantly on the back of massive capital inflows. As a result, net external indebtedness deteriorated rapidly, exceeding 110 percent of GDP in 2007, while the massive expansion of Icelandic companies and banks abroad bloated gross international liabilities to 625 percent of GDP.

\section{Policies fell short of being able to contain widening imbalances and vulnerabilities reached dangerous levels:}

- $\quad$ Fiscal policy was loose. While the general government recorded surpluses which were among the highest among the advanced economies during 2004-07, revenues were artificially elevated by the booming domestic demand, buoyant construction, and inflated asset prices, suggesting significantly weaker cyclically-adjusted balances.

- $\quad$ Financial sector regulation and supervision lagged behind, in part because a macroprudential toolkit was lacking. The relaxation of lending standards at the outset of the lending boom (HFF loosened loan-to-value ratio in mid-2004) further undermined the effect of the monetary tightening. Also, the Financial Supervisory Authority (FME) was overpowered by the influential banking sector, leaving risks related to cross-shareholdings and connected lending unaddressed.

- $\quad$ Monetary policy tightening was insufficient. Monetary transmission has been weakened by the lumpy capital inflows and loan indexation, and loose fiscal policy has further complicated monetary policy conduct. In this environment, the policy tightening initiated in early-2004 had only a limited impact on domestic demand and inflation.

7. Fund surveillance during the upswing was not sufficiently candid in indentifying the rising systemic risks. While praising strong economic growth, staff worried about the possibility of overheating, emphasizing growing imbalances reflected in high inflation and large current account deficits. Staff recommended tighter monetary policy and pointed to fiscal policy as the 
principal adjustment mechanism during the investment- and consumption-led boom, but was generally sanguine about Iceland's overall growth prospects, with the 2007 Article IV report concluding that "Open and flexible markets, sound institutions... have enabled Iceland to benefit from the opportunities afforded by globalization." While the scale of the shock and tensions triggered by Lehman's bankruptcy were difficult to foresee, the Fund did not highlight the exceptionally large banking sector as a key vulnerability that needed to be addressed urgently. Staff identified liquidity, credit expansion, and equity crossholdings as key risks in the banking sector, but viewed them to be manageable. The gradual strengthening of banking supervision and regulation was regarded as an adequate safeguard against the materialization of risks.

\section{Against this background, the $\mathbf{2 0 0 8}$ global financial turmoil laid bare Iceland's} vulnerabilities, pushing the country into a deep financial and economic crisis. Icelandic banks were cut off from wholesale financing, and a brief attempt to nationalize one of them revealed the severe problems facing the banks which contributed to a downgrade of the sovereign, as the banking system was 'too big-to-save' relative to the size of the economy. The three largest banks collapsed within a week in October 2008. The failed banks were split into 'new' and 'old' entities and their non-depositor creditors were left with claims on the 'old' banks assets, subordinate to the claims of depositors and deposit insurance. Confidence collapsed and the króna and other asset prices were in freefall. The exchange rate market ceased to operate and as reserves dwindled, in mid-October 2008 the Central Bank of Iceland (CBI) imposed tight controls and foreign exchange rationing through daily auctions. Real GDP and domestic demand declined cumulatively by a staggering $10 \frac{1}{2}$ and 23 percent, respectively during 2009-10.

\section{Key Aspects of Program Design and Exceptional ACCess}

\section{A. Program Design}

\section{The SBA approved in 2008 projected a sharp decline in output, followed by a} relatively fast export-led recovery and a quick decline of inflation (Figure 1). While the output decline in 2009 turned out smaller than initially forecast, in part due to fiscal support, the recovery was more protracted. This reflected both weaker-than-expected external environment and sluggish domestic demand, constrained by the high private sector debt as progress on debt restructuring was initially slow. At the same time, inflation proved more persistent, declining towards its target at a slower-than-projected pace. Overall, fiscal outcomes (primary balance and gross public debt) turned out better than initially projected, reflecting sizable consolidation and strong commitment by the authorities to limit absorption of bank restructuring costs by public finances.

\section{Given the unprecedented size and scope of the financial and economic crisis, the} program was designed to restore confidence and stabilize the economy. Accordingly, the program's key objectives were: (i) restoring early confidence in the króna by stemming its depreciation (an immediate priority), including through the use of capital controls $;^{5}$ (ii) putting

\footnotetext{
${ }^{5}$ The rules of capital controls established in late 2008 included: (i) restrictions on capital transactions for residents and non-residents, limiting their ability to shift funds between króna and foreign exchange; (ii) a ban on conversion of króna denominated bonds and other similar instruments to foreign currency upon maturity; the proceeds must be
} 
public finances on a sustainable path through a multi-year fiscal consolidation program consistent with debt sustainability and supported by gradualism in capital account liberalization to avoid exacerbating external instability; and (iii) rebuilding the banking system on a sound basis and implementing private debt restructuring, while limiting the absorption of banking crisis costs by the public sector. Fund financing was appropriately aimed at shoring up the low levels of international reserves, while strengthening investor confidence and Iceland's external financing capacity.

\section{Policy implementation was broadly on track, though the elections in early-2009 and} Icesave-related issues delayed somewhat program reviews and disbursements. The first review was delayed following the collapse of the government in early 2009 and the formation of a new government. ${ }^{6}$ The delay allowed a government level agreement to be finalized with the United Kingdom and the Netherlands to partially guarantee Icesave deposit insurance (Box 1). ${ }^{7}$ The delay necessitated an initial extension of the program and a rephasing of the remaining disbursements. The second review was also delayed due to the need to ensure financing assurances, while delays associated with the fifth review were related to uncertainties about how the Icesave dispute would be resolved and the potential economic impact, as well as additional time needed by the authorities to formulate Iceland: Access and Phasing of the 2008 Stand-by Arrangement

\begin{tabular}{|c|c|c|c|}
\hline & $\begin{array}{c}\text { Completed } \\
\text { (Delay) }\end{array}$ & Access Rephased & $\begin{array}{r}\text { End of SBA } \\
\text { (Extension) }\end{array}$ \\
\hline SBA & November 2008 & - & October 2010 \\
\hline First Review & $\begin{array}{c}\text { October } 2009 \\
\text { (7 months) }\end{array}$ & Yes & $\begin{array}{l}\text { May } 2011 \\
\text { (6 months) }\end{array}$ \\
\hline Second Review & $\begin{array}{l}\text { April } 2010 \\
(3 \text { months })\end{array}$ & $\begin{array}{l}\text { Yes } \\
\text { 8th review eliminated; disbursement spread } \\
\text { over } 5 \text { th }-7 \text { th reviews }\end{array}$ & $\begin{array}{c}\text { August } 2011 \\
\text { (2 months) }\end{array}$ \\
\hline Third Review & September 2010 & - & August 2011 \\
\hline Fourth Review & January 2011 & - & August 2011 \\
\hline Fifth Review & $\begin{array}{c}\text { June } 2011 \\
\text { (3 months) }\end{array}$ & $\begin{array}{l}\text { Yes } \\
\text { two last purchases available in single } \\
\text { tranche upon completion of final review }\end{array}$ & August 2011 \\
\hline Sixth Review & August 2011 & - & August 2011 \\
\hline
\end{tabular}

key policies. ${ }^{8}$ The sixth and final review was completed on time, while the bilateral partners extended their outstanding loan commitments to end-2011.

reinvested in other króna instruments; (iii) a requirement for residents to repatriate all foreign currency that they acquire. Certain companies, including major exporters and firms with large international operations, were given full or partial exemption from the rules upon fulfillment of certain criteria. Also, payments linked to current account transactions and inward FDI were released after a short period of time.

${ }^{6}$ The political crisis stalled policy implementation - quantitative floors for end-December 2008 on the changes in net international reserves of the CBI, and central government net financial balance (deficit) were missed but subsequent indicative targets and cumulative performance criteria were met.

${ }^{7}$ The agreement with the United Kingdom and Netherlands was that deposit insurance in the foreign branches of Landsbanki would be covered by a loan to the Icelandic Deposit Guarantee Fund, guaranteed by the Government of Iceland, whereby the payments to deposit holders from the assets of the failed bank would decrease the outstanding amount. In December 2011, the Resolution Committee of Landsbanki has made the first partial payments to priority creditors, covering close to one-third of the recognized priority claims (ISK 432 billion).

${ }^{8}$ The fifth review was also delayed because the authorities needed more time to formulate their revised strategy for capital account liberalization. 


\section{Box 1. Icesave: Background and Implications for Financing Assurances}

\section{Icesave was an overseas online savings account brand owned and operated by} Landsbanki during 2006-08. It operated in the United Kingdom (from October 2006) and the Netherlands (from May 2008). At the time of Landsbanki's collapse, Icesave had over 300,000 customers in the United Kingdom, with deposits of over $£ 4$ billion ( $€ 5$ billion). In the five months that it operated in the Netherlands, Icesave attracted more than 125,000 customers and $€ 1.7$ billion of deposits (all Icesave deposits were about 60 percent of GDP in 2008).

The Icesave dispute arose when Landsbanki failed, prompting the British and Dutch governments to intervene and protect local Icesave depositors. Iceland's (private) deposit insurance fund was unable to reimburse depositors in Landsbanki's foreign branches. To safeguard financial stability in their own countries, the British and Dutch governments stepped in to pay out their depositors. The British and Dutch governments, however, maintained that the Icelandic government had a legal obligation under European Economic Area (EEA) law to provide a sovereign guarantee to the deposit insurance fund and therefore sought repayment from the Icelandic government. The Icelandic authorities, however, were of the view that Iceland did not have a legal obligation under EEA law, but indicated that they were nonetheless ready to seek a negotiated solution to the Icesave dispute.

Negotiations between Iceland, the United Kingdom, and the Netherlands to resolve the Icesave issue carried on for over 2 years. A first agreement was reached in June 2009, but was never implemented, because Iceland's parliament did not support it and therefore limited the government's guarantee in a manner that was unacceptable to the United Kingdom and the Netherlands. A second agreement was reached in October 2009 and approved by the Icelandic Parliament in December 2009. However, the President of Iceland did not sign the legislation and the issue was put to a national referendum, where it was resoundingly rejected (March 2010). A third agreement was reached in December 2010 and approved by the Icelandic Parliament in February 2011 but was not signed by the President. Thus, in April 2011, another referendum was held and the agreement was again rejected by the Icelandic public. The Icesave dispute was brought to EFTA Court and is now being settled through legal channels.

Against this background, the Icesave dispute affected financing assurances under the program, which contributed to delays in completing some program reviews. While an Icesave agreement was not part of program conditionality, some program reviews were delayed because of the need to reassess financing assurances from the Nordics, who linked their financing to progress on resolving the Icesave dispute. 


\section{The policies under the program were appropriately focused and sequenced. The} initial policies (and conditionality) aimed at anchoring macroeconomic stability by curbing the free fall of the króna through a combination of interest rate policy, liquidity management, foreign exchange interventions, and restrictions on capital outflows. Imposing capital controls helped avoid a further sharp depreciation and exchange rate overshooting, given the very large size of nonresident claims (króna holdings estimated at \$5 billion, or about 40 percent of GDP in 2008). Exchange rate overshooting could have had a damaging impact on balance sheets, given currency mismatches, CPI-indexation of household debt, and high exchange rate pass through to inflation. Thus, capital controls helped avoid a much deeper contraction that would have occurred with reliance on higher interest rates. The program envisaged a gradual liberalization of capital controls, once macroeconomic stability was more established and credibility enhanced by access to international credit markets. In the interim, the initially tight monetary policy was gradually eased to support output recovery as the exchange rate stabilized.

\section{As a whole, structural conditionality (cumulative) of the Iceland SBA was in line} with the average for all Fund-supported programs since 2002. However, given the extensive financial sector crisis, conditionality in this area was twice the average for the Fund-supported programs. Monetary and exchange rate policy conditionality was only slightly above the average, reflecting the focus of the Iceland SBA on stabilizing the currency and strengthening monetary operations. While fiscal

Iceland: Structural Conditionality Relative to Recent Fund-supported Programs 1/

\begin{tabular}{lcc}
\hline & $\begin{array}{c}\text { Average per } \\
\text { country }\end{array}$ & Iceland \\
\hline Fiscal policy & 7 & 5 \\
Monetary and exchange rate policy & 3 & 4 \\
Public enterprise reform (privatization) & 1 & 1 \\
Public sector accountability & 6 & 4 \\
Financial sector & 9 & 17 \\
Other 2/ & 6 & 0 \\
Total & 32 & 31 \\
\hline
\end{tabular}

Sourcess: IMF, MONA database; and IMF staff estimates and calculations.

1 / General resoures account programs since 2002; cumulative.

2/ Labor market reforms, economic statistics, other structural measures.

policy reforms were central to the program, this did not result in above-average structural conditionality, partly reflecting the reliance on other quantitative performance criteria (PC) and indicative targets. Following the initial delays due to the elections and the need to ensure existence of financing assurances, all structural benchmarks were met, and the structural and quantitative PC were nearly all met (Table 3 ).

\section{The program carried high risks, but these were broadly well-managed (Box 2).}

Initial uncertainties about crisis-related bank restructuring costs posed major risks to the program but were mitigated by the authorities' commitment to a prudent fiscal consolidation plan and subsequent actions to minimize costs to the public sector from bank restructuring, which was designed in the program. The significant risk of large capital outflows was mitigated by capital controls and the focus of monetary and exchange rate policies on building confidence (through exchange rate stabilization) and accumulating adequate international reserves. The sizable total external debt posed significant adjustment challenges, while the large and growing public debt (projected at 125 percent of GDP in 2009 at the fist review) posed high risks to solvency. To address fiscal solvency concerns, performance criteria were therefore set on the pace of public debt accumulation and on the central government's fiscal balance to help mitigate these risks. 


\section{Box 2. Key Litigation Risks}

\section{The Icesave dispute and challenges to the Emergency Law have been the two key (separate but related) litigation risks to the program.}

- The first risk has arisen from depositors' claims on Old Landsbanki (the Icesave dispute). Iceland's obligation under the EU directive on deposit insurance has been uncertain, with potential outcomes from the legal procedures being: no obligation, coverage of insured deposits only, and coverage of all deposits.

- $\quad$ The second risk has stemmed from other creditors challenges to the Emergency Law which ranked (retail and wholesale) depositors ahead of unsecured creditors (including foreign banks and bondholders) in insolvency proceedings. Overturning depositor priority would have exacerbated Icesave risks significantly, because a pari passu treatment of unsecured creditors and depositors would have left a smaller fraction of depositors to be covered by the assets of the Old Landsbanki, putting a heavy burden on public finances.

\section{In October 2011, Iceland's Supreme Court ruled to uphold the Emergency Law,} which has significantly reduced litigation risks. This ruling followed a similar finding by the EFTA Surveillance Authority in December 2010. The remaining risks arising from the Icesave dispute are mitigated by the fact that Landsbanki's estate is currently estimated to cover 100 percent of the Icesave deposits.

\section{Notwithstanding the risks, the program struck a balance between short- and} medium-term objectives through appropriate sequencing and flexibility. Recognizing the dangers of massive capital outflows and disorderly deleveraging, capital controls were used to stabilize the exchange rate. The Fund balanced well between the need to ensure fiscal sustainability and support the economy by modifying the program as needed. Specifically, the fiscal program shifted gear from accommodation to a frontloaded consolidation in the second half of 2009 , with strong endorsement by both the newlyelected government as well as social partners (unions and employers) who agreed to nominal wage cuts. Later on the program was recalibrated, as firm implementation of measures by the authorities, supported by modest economic recovery and containment of public debt, allowed for a more measured pace of consolidation, while safeguarding sustainability. Finally, the program usefully drew on the pace and design of Nordic

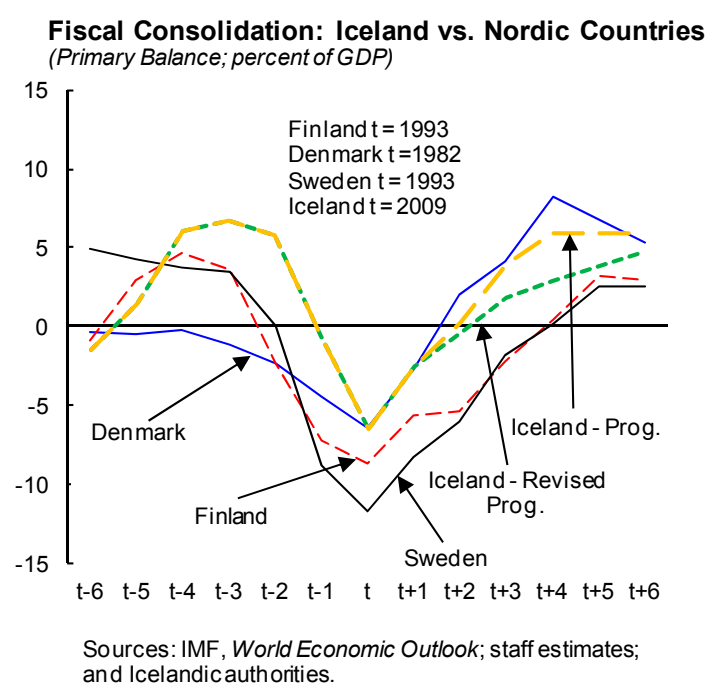
and Icelandicauthorities. consolidations in the 1980-1990s, which reassured the markets about their feasibility in Iceland, given the similarities in socio-economic characteristics and overall macro contexts. 


\section{B. Financing and Adjustment Mix}

16. To address the immediate balance of payments need, the SBA had high access and was frontloaded. The Fund's financing package - representing 42 percent of the 2008-10 financing need, was set at SDR 1,400 million (1,190 percent of quota or 12.5 percent of GDP), with a first upfront disbursement of SDR 560 million (476.2 percent of quota) to be followed by eight equal installments of SDR 105 million subject to quarterly reviews.

17. The frontloading of Fund financing was comparable to other recent programs, while phased access was appropriately linked to the pace of program implementation. At 40 percent of total approved financing, the frontloading was above the median level of about 30 percent of recent resent crisis cases. The level of access both in quota and GDP terms was very high, reflecting the unprecedented scale of the Iceland: Access and Phasing Relative to Recent Programs $1 /$ banking system relative to Iceland's domestic economy. By end 2007, the banking system had accumulated assets of over 900 percent of GDP and gross external indebtedness was 550 percent of GDP, largely on account of the banks' exposure (external

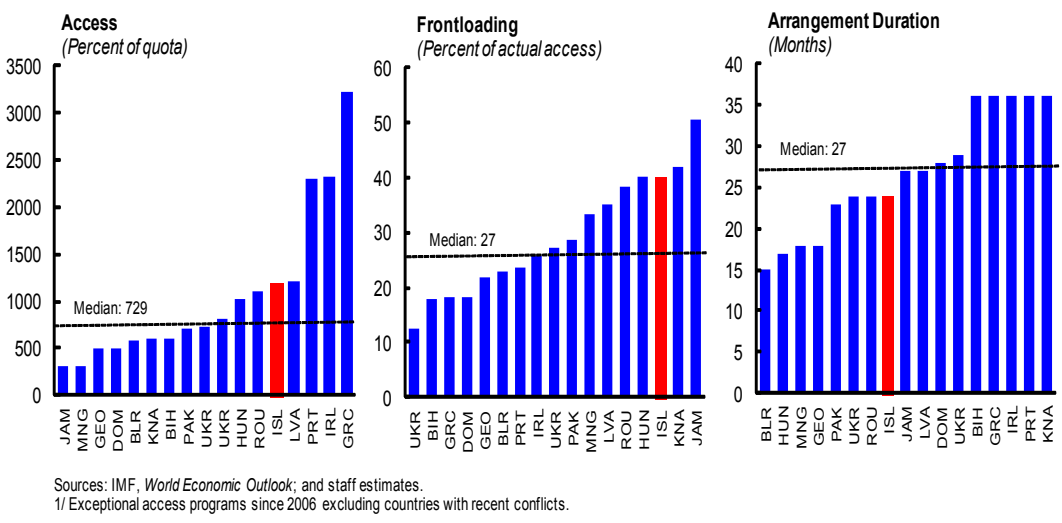
arrears on obligations of the three intervened banks were estimated at $\$ 10.3$ billion in 2008).

\section{Justification of Exceptional Access}

18. While the program carried high risks, all four criteria for exceptional access were met at the time of the SBA agreement. ${ }^{9}$ Specifically:

- $\quad$ First criterion: "balance of payments pressures on the capital account resulting in a need for Fund financing that cannot be met within the normal limits." In late 2008, Iceland faced severe external payments crisis, with the current account deficit projected at around 11 percent of GDP, net financial and capital outflows of about 120 percent of GDP, and massive króna depreciation of 65 percent on a trade weighted basis. Given the low reserve levels and very large banking sector external liabilities (gross liabilities to nonresidents of 600 percent of GDP), the Fund supported capital controls to stem additional flight of capital, given the loss of confidence. There was an urgent need to build a reserves buffer to help restore confidence and reverse the overshooting of the exchange rate.

\footnotetext{
${ }^{9}$ Since Iceland's program was approved before the Board decisions that modified exceptional access criteria (GRA Lending Toolkit and Conditionality-Reform Proposals, 3/19/09), its request for exceptional access is assessed under the old criteria (PIN 03/37, 3/21/03).
} 
- $\quad$ Second criterion: "a rigorous and systematic analysis indicates that there is a high probability that debt will remain sustainable." As a result of the crisis, gross public external debt and total external debt for 2009 were projected at 95 and 160 percent of GDP, respectively. Staff analysis, however, suggested that there was significant potential for bank external asset recoveries to finance claims on foreign deposits. Together with the authorities' commitment not to absorb losses from the banking crisis by public sector and a resolute medium-term fiscal adjustment plan supported by the Fund-supported program, these efforts were expected to help put the public sector debt on a sustainable path by 2013. Staff estimates when the SBA was approved in 2008 envisaged gross public debt and total external debt to decline to about 93 and around 100 percent of GDP, respectively.

- Third criterion: "good prospects of regaining market access within the time that Fund resources would be outstanding, so that the Fund's financing would provide a bridge." Under the program, staff projected that once the current crisis was resolved, capital controls are removed, and the economy adjusts, Iceland would be able to regain market access relatively quickly (within the maturity of credit tranche resources). Reassuringly, access to the international markets was regained in June 2011 (prior to completion of the program) with the government successfully issuing its first post-crisis international sovereign bond.

- Fourth criterion: "the policy program of the member provides a reasonably strong prospect of success, including not only the member's adjustment plan but also its institutional and political capacity to deliver that adjustment." The program initially focused on three critical goals: restoring confidence in the exchange rate, resolution of the banking sector and medium-term fiscal consolidation. Notwithstanding implementation risks, Iceland's broad consensus on the objectives of the program set the stage for the needed adjustments to complete the program successfully, reflecting firm significant policy accomplishments supported by strong ownership.

\section{Policy Assessment}

\section{A. Financial Sector}

\section{The authorities' pre-SBA response to the crisis}

\section{Following the collapse of the Iceland banking system, the authorities had few} options but to ring-fence domestic stakeholders to preserve the financial system. The main objectives of the authorities' strategy were to: (i) preserve the functioning off the domestic payment system; (ii) limit the absorption of private sector losses by public sector; and (iii) create the conditions for rebuilding a domestic-banking system. The government extended a blanket guarantee to domestic depositors to stem bank runs and imposed controls on capital outflows to maintain domestic liquidity and avoid additional pressure on the exchange rate. The Emergency Act (October 6, 2008) empowered the FME with broad-based powers to intervene in failing institutions, granted all deposits seniority over the unsecured claims in case of bank failures, and 
allowed government to inject capital into the newly created domestic banks that were carved out from the failed banks.

20. While the authorities' old/new bank restructuring approach had shortcomings, it ensured the continuity of vital domestic banking services. The authorities did not follow an established good-bank/bad-bank approach. Instead, they split the failed banks along domestic/foreign lines. ${ }^{10}$ This approach had some shortcomings, in particular: (i) the evaluation process proved extremely difficult, time-consuming, and contentious, thus delaying the recapitalization of the new banks; (ii) the new banks remained with a large share of nonperforming loans (NPL) - 45 percent of total loans in late 2008, leaving the resumption of the new banks' intermediation function dependent upon a successful private-sector debt restructuring; and (iii) the new banks remained vulnerable to exchange rate fluctuations, given their substantial net open foreign currency positions, as a large share of domestic loans was denominated in foreign currency or indexed to the exchange rate. However, the approach had crucial benefits - it preserved the functioning of domestic payment system (domestic payments and transaction accounts), achieved an immediate downsizing of the banking sector, and solved the problem of excessive reliance on wholesale funding as the new institutions were largely funded by deposits.

\section{The IMF-supported program}

21. The program strategy for the financial sector had three main objectives. The first key objective was restoring banking sector's financial intermediation capabilities through the restructuring of its business activities and strengthening of its capital buffers. Given that the authorities had already implemented the new/old bank split, the staff's goal was to find a comprehensive and sound strategy that was nondiscriminatory, cooperative, and minimized costs for Icelandic taxpayers. The second objective was reducing the private sector's debt overhang to support viable debtors while safeguarding credit discipline; and, the third objective was strengthening prudential regulation and supervisory practices.

\footnotetext{
${ }^{10}$ The new banks (Arion Banki, Islandsbanki, and Landsbankinn) were created by transferring the domestic assets (written down by 50-60 percent) and deposits of the three major failed banks (Kaputhing, Glintir, and Landisbanki), which were placed into receivership under the control of Resolution Committees. In the original plan, the three new banks were expected to issue compensation bonds to reimburse creditors of the old banks for any excess of assets over liabilities transferred.
} 


\section{Banking sector restructuring}

22. The banking sector has been restructured by securing significant private sector involvement and through public sector action, though at some cost. To mitigate liquidity risks, create sufficient buffers to absorb potential losses, and prompt the restructuring process, minimum capital requirements were set at a high level (16 percent for total capital adequacy and 12 percent for Tier 1 capital). To limit the costs to the public sector, creditors of the new domestic banks were offered the option of converting their claims into equity holdings, thereby granting them potential upside gains insofar recovery rates turned out to be higher-than-originally estimated. Accordingly, given the difficulties in valuing the assets of the three large failed

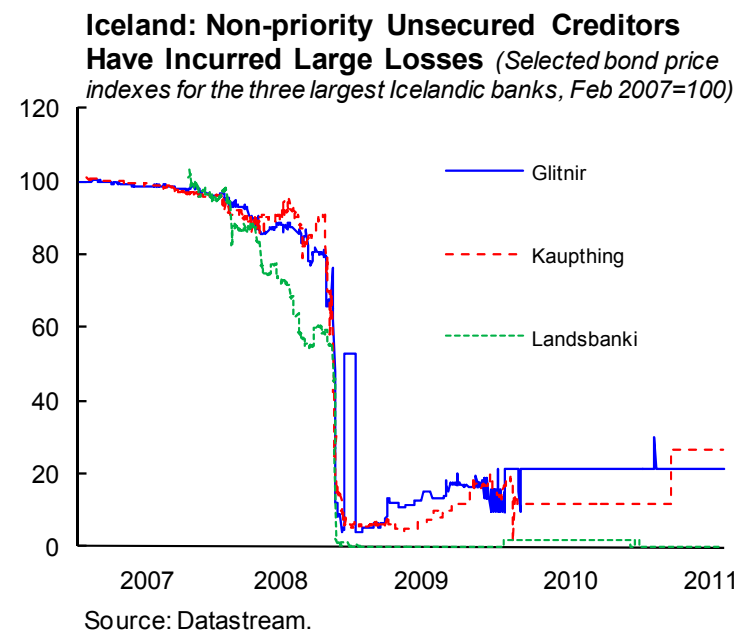
banks, an agreement was reached whereby the creditors of the old banks became the shareholders of two of the new banks through a debtto-equity swap operation (the third one remained fully state-owned), instead of receiving a compensatory note. ${ }^{11}$ The severely undercapitalized part of the savings banks sector was also intervened and either sold to other banks, resolved through purchase, or liquidated. ${ }^{12}$ Leasing and credit card management companies were restructured without public support. The net fiscal costs of the banking crisis are estimated at about 20 percent of GDP, with significant portion attributable to losses on loans made by the CBI in the months before the banks failed (Text table).

\footnotetext{
${ }^{11}$ To help insulate state participation in the banking industry from political pressure, a separate agency (the Icelandic State Financial Investments-ISFI) was created. The function of ISFI is to ensure good administration and business practices and supply funds on behalf of the Treasury, based on authorizations in the budget act.

${ }^{12}$ The number of savings banks fell from 20 to 10 . While the Treasury remains the major shareholder in five savings banks and has to privatize them going forward, their share in the banking system is very small (less than 1 percent of GDP).
} 
Iceland: Government Debt Incurred as a Result of Bank Support and Restructuring During the Crisis (In percent of GDP)

\begin{tabular}{|c|c|c|c|c|c|}
\hline & 2008 & 2009 & 2010 & 2011 & Total \\
\hline Write offs $1 /$ & 13.0 & 2.3 & 3.9 & 0.0 & 19.2 \\
\hline Securities lending $2 /$ & 6.2 & 0.0 & 0.0 & 0.0 & 6.2 \\
\hline Central Bank recapitalization & 6.8 & 0.0 & 0.0 & 0.0 & 6.8 \\
\hline Commercial bank recapitalization 3/ & 0.0 & 2.3 & 0.0 & 0.0 & 2.3 \\
\hline Recapitalization of the House Financing Fund & 0.0 & 0.0 & 2.2 & 0.0 & 2.2 \\
\hline "Savings Banks" & 0.0 & 0.0 & 0.0 & 0.0 & 0.0 \\
\hline Called guarantees of the State Guarantee Fund 4/ & 0.0 & 0.0 & 1.8 & 0.0 & 1.8 \\
\hline Public debt incurred with acquisition of assets & 11.5 & 12.5 & 0.0 & 0.0 & 23.9 \\
\hline Central bank recapitalization & 11.5 & 0.0 & 0.0 & 0.0 & 11.5 \\
\hline Commercial bank recapitalization & 0.0 & 12.5 & 0.0 & 0.0 & 12.5 \\
\hline Gross fiscal cost of bank support and restructuring & 24.4 & 14.8 & 3.9 & 0.0 & 43.1 \\
\hline Net fiscal cost of bank support and restructuring & 13.0 & 2.3 & 3.9 & 0.0 & 19.2 \\
\hline
\end{tabular}

23. The banking sector was significantly downsized, reducing risks, although the three largest banks remain quite large compared to the size of the Icelandic economy. The total assets of the three largest banks declined to about 190 per cent of GDP by end-2010, significantly lower than the close to 870 percent of GDP in 2007. While the too-big-to fail/too-big-to-rescue problem persist, scaling down the new banks even further was not considered a feasible solution due to two reasons. First, it would have reignited tensions about asset valuation as further breakup of the new banks would have required asset re-evaluation. Second, it would have limited banks business diversification (exposure to single large business), aggravating risk concentration (on banks assets or liabilities or both),

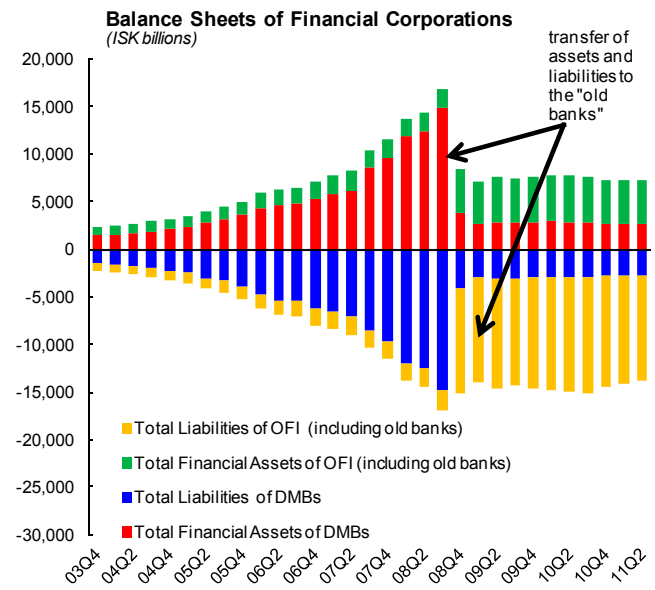
given the presence of large borrowers and depositors. As banking sector concentration seems an unavoidable "curse" of small economies, to mitigate risks, more stringent regulatory regime and more pro-active, intensive, and comprehensive supervision were a critical component of the program and will need to be intensified going forward.

\section{Despite strengthening their capital buffers, banks have not resumed their core}

lending activity. Credit conditions have remained very tight since the crisis. This development has reflected both supply (risk aversion, deleveraging) and demand factors (debt workout, weak economic outlook, unemployment). Also, both lenders and borrowers have been deeply affected by the crisis and therefore, it is difficult to envisage a recovery in lending activity until the process of private sector debt restructuring has been further advanced.

25. The Housing Finance Fund (HFF) continues to enjoy a preferential regime but the authorities plan to review the status of that regime. Owing to incurred losses, the state made a 
capital injection equivalent to 2.1 per cent of 2010 GDP to bring its capital to about 2 percent of risk-weighted assets. The authorities are in the process of assessing HFF's capital needs with a view of injecting additional funds, if needed, to increase the capital of HFF to its traditional level (5 percent). Also, they intend to take further steps towards reforming HFF based on the findings of a report on the future of the financial system and its supervision prepared by the Ministry of Economic Affairs. Furthermore, in July the EFTA Surveillance Authority (ESA) has recommended certain measures bringing the HFF in line with the state aid provisions of the EEA Agreement by end-2011. ${ }^{13}$

\section{Private sector debt restructuring}

26. Iceland had to deal with a private sector debt overhang problem of unprecedented proportions after the crisis. In the run-up to the crisis, total private sector debt tripled, reaching over 450 percent of GDP by end-2008, with household and corporate debt at about 130 and 340 percent of GDP, respectively. Also, at the time of the crisis, private debt in Iceland was significantly higher than private debt in countries that have experienced financial crisis in the past, notably the Nordic financial crisis during the 1980-1990s and the

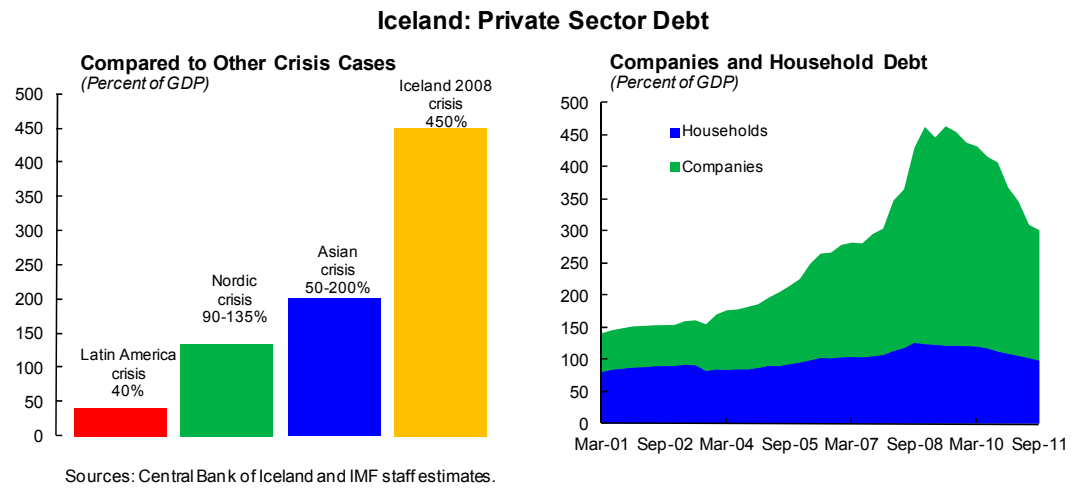
1997-98 Asian crisis.

\section{Given the scale of the problem, progress on private sector debt restructuring was} initially slow due to a number of factors, but accelerated towards the end of the program (Figure 2). The authorities' approach favored market-based voluntary workouts and strengthening the legal framework. ${ }^{14}$ The framework for household and corporate debt restructuring was built up in stages during the program, with input from Fund staff, and aimed to encourage and expedite voluntary out-of-court workouts (given also limited court capacity); expand the coverage of debt-distressed individuals; reduce conflict of interest among creditors (the "hold out" problem) and asymmetry of information between debtors and creditors. These successive adjustments fueled private sector expectations of more generous debt relief offers in

\footnotetext{
${ }^{13}$ Amongst other things, the ESA requested Iceland to clarify the definition of the public service entrusted to HFF by introducing caps on cost and size of the dwellings eligible for HFF funding.

${ }^{14}$ Initially, Fund staff and authorities contemplated the idea of establishing an Asset Management Company (first review). This could have helped reducing the uncertainty about banks' balance sheet. However, the idea was subsequently dismissed (second review) on the ground that it would have entailed delays in the process due to the need to set up a new authority; upfront additional costs for the state, whose financial conditions were already distressed; and renewed conflicts with the new bank shareholders about asset valuation, which had been already marked down.
} 
the future, holding back potential settlements. ${ }^{15}$ Following the October 2009 accord on payment smoothing, the authorities agreed with lenders towards the end of the program (December 2010) on a comprehensive package of measures and clearly indicated, as suggested by Fund staff, a sunset clause for the restructuring offer (mid-2011). Since then, the pace of private sector debt restructuring has accelerated, although the latest Supreme Court ruling (February 2012) may result in further delays of private debt restructuring.

\section{Strengthening prudential regulation and supervision}

\section{Legislation has been passed to rectify most of the regulatory failures that} contributed to the Icelandic banking crises and further reforms are planned. In November 2008, as part of the Fund-program conditionality, the Icelandic authorities tasked an experienced bank supervisor to assess the regulatory framework and supervisory practices in Iceland and propose needed changes. ${ }^{16}$ The major recommendations of the Jännäri Report included strengthening the discretionary powers of the FME; establishing a national credit registry at the FME; tightening provisions on large exposures, connected lending, and related party loans; toughening fit-and-proper requirements for owners; and enhancing cooperation of the FME with external auditors. These recommendations were incorporated in an amendment (Act No.75/2010) to the Act on Financial Undertakings that was approved in June 2010. In addition, a bill is pending in parliament on revising deposit insurance legislation in line with recently introduced changes in European legislation. The new limited deposit guarantee arrangements will eventually replace the current blanket deposit guarantee.

\section{While supervision was strengthened in the course of the SBA, some streamlining of} the supervisory architecture could be considered in the future. The responsibility of regulating the financial sector in Iceland is shared by a number of Ministries ${ }^{17}$, with the FME being the unified supervisory agency. This complicated arrangement can create some overlapping and is prone to problems of coordination failures. Indeed, one of the recommendations of the Jännäri Report was to rationalize this web of financial sector regulators. The option of creating a single supervisor by merging the FME and CBI was discussed under the program. However, since the international experience showed that there was no single "best" institutional structure for financial supervision, the authorities decided to keep the FME independent. ${ }^{18}$ While this decision was appropriate, given uncertainty in the midst of the crisis,

\footnotetext{
${ }^{15}$ The Supreme Court decisions (June and September 2010, and May 2011) also contributed to the delays in the process, by creating uncertainty about the value of the debt.

${ }^{16}$ Kaarlo Jännäri, retired Director General of the Finnish Financial Supervisory Authority, was engaged to carry out the assessment.

${ }^{17}$ The Ministry of Economic Affairs (MoEA), created during the program period, is responsible for financial sector legislation, excluding pension fund legislation; the Ministry of Finance, which plays by definition a crucial role in crisis management, is responsible for pension fund legislation, and the Ministry of Social Affairs and Social Security (which is part of the Ministry of Welfare) oversees the HFF activities.

${ }^{18}$ Their decision was based also on the fact that the supervisory arrangement included several elements intended to strengthen coordination, in particular: (i) the CBI has been represented at the FME's board by either the Governor or the Deputy Governor (except for a brief period after the collapse of the banks); (ii) a Memorandum of
}

(continued...) 
going forward, the current arrangement could be assessed in a couple of years and, if coordination were found to be ineffective, consideration could be given to tasking the CBI with supervision. Having supervision within the CBI could help integrate micro- and macroprudential oversight of the financial system, improve the sharing of relevant information, and generate some economies of scale, given the limited availability of human resources.

30. Also, the supervisory culture needs to be enhanced, which will require time and resources. A review of the compliance with the Basel Committee Core Principle (BCP) for effective supervision found that the key issues remain to be implemented, which is delayed by institutional capacity, and importantly, the need of a consistent framework or risk model. ${ }^{19}$ The FME is taking steps to address the remaining supervisory gaps but this will require time and resources.

\section{Program conditionality}

31. During the program, financial sector conditionality was appropriately adapted to the complexities and medium-term nature of financial sector reform. At the beginning of the program, in line with the objective of establishing credibility, half of the financial sector conditions were prior actions and structural performance criteria. Over time, the intensity and stringency of conditionality was gradually reduced and structural performance criteria were eliminated to better accommodate the complexity of the reform process. This had also the advantage of preventing the program from being hostage to a hard-time schedule.

\section{B. Fiscal Policy}

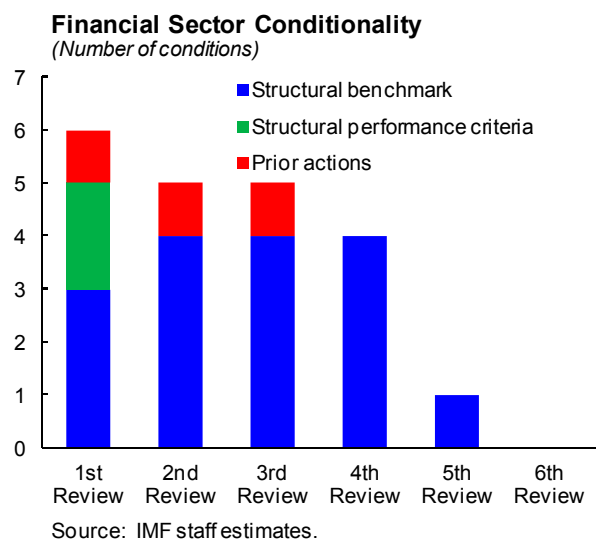

32. A sizable fiscal consolidation was implemented and fiscal efforts should continue to secure sustainability. The authorities implemented an impressive fiscal consolidation, amounting to over 9 percent of GDP during 2009-2011, with the bulk of the adjustment achieved within 2 years (2009-2010). The composition of measures was well balanced between revenues and expenditures. ${ }^{20}$ Tax increases were spread across all major taxes, including social security contributions. Expenditure cuts covered all budget categories, including gross fixed capital formation and compensation of employees, while social benefits were safeguarded in line the

Understanding between the CBI and FME has been signed; and (iii) both the CBI and FME were put under the umbrella of the MoEA.

\footnotetext{
${ }^{19}$ In mid-March 2011, the FME completed a self-assessment of the country's compliance with the BCP that was subjected to an independent evaluation by a well-known foreign assessor.

${ }^{20}$ Technical Assistance (TA) from the IMF's Fiscal Affairs Department (FAD) has been helpful in identifying revenue measures. Currently the authorities are discussing and preparing a package of tax measures on environmental and energy taxation, following TA in May 2011.
} 
authorities' post crisis objective of maintaining the key elements of the Icelandic welfare state. This was achieved by designing the fiscal consolidation in a way that sought to protect vulnerable groups by having expenditure cuts that did not compromise welfare benefits and raising revenue by placing greater tax burden on higher income groups. Public administration was significantly streamlined and cost-reducing reforms in education and healthcare were initiated. ${ }^{21}$ The involvement of social partners at an early stage of the negotiations also helped by forging broader ownership. At the same time, while fiscal risks associated with the financial sector restructuring have been contained, external environment has become more difficult, and credibility in financial markets has yet to be fully established. Therefore, considering the upcoming election cycle, concerted consolidation effort would be needed to ensure that public finances remain on a sustainable path.

\section{Fiscal targets were appropriately eased during the program, while keeping a} balance between securing sustainability, supporting the economy, and preserving social objectives. The authorities faced a difficult trade-off between securing fiscal sustainability and

mitigating the risks of exacerbating the recession in the near term. In that context, and consistent with program design, the authorities initially allowed automatic stabilizers to operate fully, switching gear in the second half of 2009 by approving an ambitious frontloaded medium-term consolidation plan $^{22}$ (a program structural benchmark),

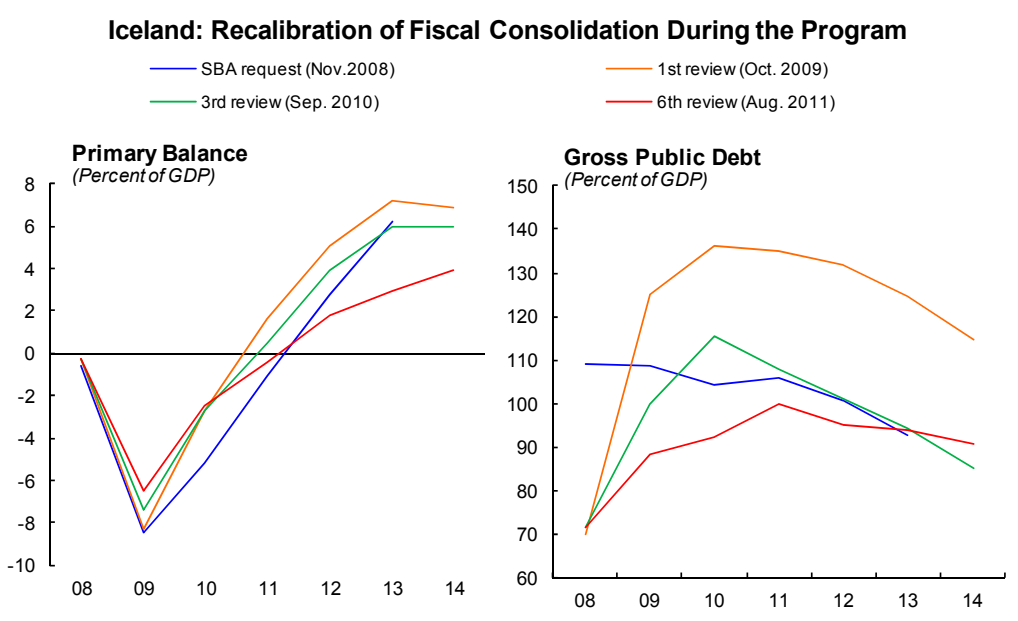

following extensive discussions with social partners that increased its credibility. The consolidation path was adjusted, with the fiscal targets eased somewhat in the second half of the program, reflecting a combination of growing risks to the economic outlook, ample financing, and strong projected debt dynamics, as private sector crisis-related losses and contingent financial sector liabilities turned out smaller than initially anticipated. ${ }^{23}$ Nevertheless, the revised fiscal path remained in line with the experience of other Nordic countries' consolidation, with public debt on a declining trajectory, projected to reach 80 percent of GDP by 2016 (Table 2).

\footnotetext{
${ }^{21}$ Looking ahead, further efforts to reduce healthcare costs would be needed as estimates point to a sizable increase of the net present value of health care spending between 2010 and 2050 (Table 9, September 2011 Fiscal Monitor: http://www.imf.org/external/pubs/ft/fm/2011/02/pdf/fm1102.pdf).

${ }^{22}$ The authorities' medium-term fiscal consolidation path (Nov. 2009) envisaged an overall improvement of the primary balance of 131/2 percent of GDP during 2010-2012 (51/2 percent of GDP in 2010, 4 1/4 percent of GDP in 2011 , and $3 \frac{1}{2}$ percent of GDP in 2012).

${ }^{23}$ In the third review (October 2010) the target for the general government primary surplus for 2011 and the medium-term target were lowered by $3 / 4$ percent of GDP. The medium term target was further lowered in the sixth review (August 2011) to support the economic recovery.
} 
34. The absorption of financial sector restructuring costs was reasonably contained. The recapitalization of the banking system was achieved at a lower-than-initially estimated cost to the public finances. The actual net direct fiscal costs of financial sector restructuring turned out significantly smaller (slightly over 20 percent of GDP) than the initial estimates made at the time of the SBA request in 2008 (of about 40 percent of GDP). Instrumental in achieving this outcome were the upfront decision to limit the absorption of private sector losses by public sector and a strategy that allowed creditors to take upside but also bear costs. Fiscal costs associated with the recapitalization of the HFF and the savings banks, which occurred towards the end of the program, were also below the initial estimates.

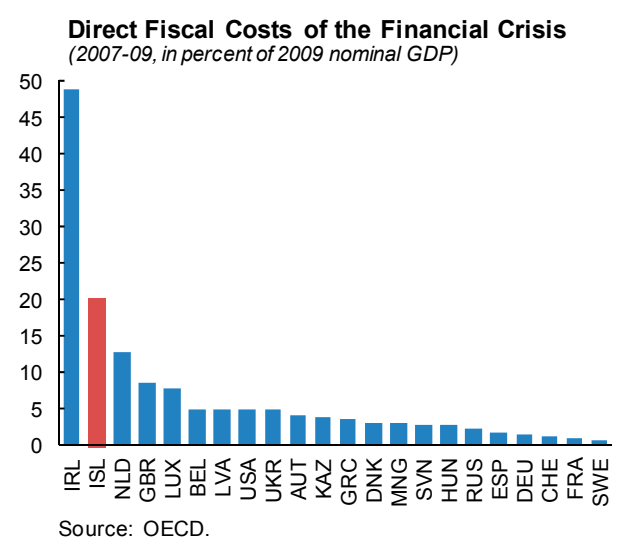

\section{The program placed a significant weight on strengthening the fiscal framework to} support securing fiscal sustainability. Iceland had weak fiscal frameworks for both central and local governments, which resulted in a spending bias and a pro-cyclical fiscal policy that exacerbated the pre-crisis boom. The new Local Government Bill (a program structural benchmark), aimed at constraining local government finances and aligning them with the consolidated central government fiscal plans, was passed by the parliament in September 2011. Following Technical Assistance from the IMF's Fiscal Affairs Department in October 2011, work is underway to strengthen further the fiscal framework and help secure fiscal sustainability. In particular, the authorities intend to present to the parliament a new Organic Budget Law by Spring 2012.

\section{Monetary Policy and Capital Controls}

\section{Monetary policy, with critical support from capital controls, averted a collapse of} the króna following the crisis and helped maintain exchange rate stability during the program. When the banking sector collapsed, confidence evaporated, the money market shrunk, despite the CBI's large liquidity injections, as investors rushed to safety, and the króna depreciated rapidly, bringing to a halt the domestic foreign exchange market. Under these circumstances, credibility of the CBI's inflation targeting regime was further damaged, accelerating capital outflows. Therefore, maintaining a stable exchange rate in the short term was set as a key program objective and an intermediate target towards the inflation objective. To prevent the collapse of the currency in the wake of the crisis, the CBI raised policy rates sharply and, given the large nonresident króna holdings, introduced capital controls, which were widely recognized as a key factor in stabilizing the currency. The authorities successfully maintained exchange rate stability throughout the program, by implementing a pragmatic combination of interest rate policy, capital controls, foreign exchange interventions, and liquidity provision.

\section{The CBI actively used interest rates to achieve the monetary policy goals of} maintaining exchange rate stability and reducing inflation. Following the failure of the banks, to stem the collapse of the currency given uncertainty in the initial effectiveness of capital controls, as a program prior action the $\mathrm{CBI}$ increased significantly the policy rate (by 600 basis 
points to 18 percent) in November 2008, reversing a significant easing (of 350 basis points) in mid-October (Figure 3). As the currency stabilized, following tighter administration of capital controls, and inflation declined sharply towards its target, the CBI embarked on a loosening cycle in early 2009. It cut interest rates to below 5 percent by end-2010, which provided support to the economy and facilitated the restructuring of household and corporate debt. However, inflation has proved highly persistent (Figure 4), while inflation expectations have been loosely anchored, underscoring the importance of enhancing the post-program monetary policy framework. ${ }^{24}$

\section{While monetary operations improved during the program, increasing interest rate} effectiveness, further progress would enhance monetary policy transmission. The CBI strengthened liquidity provision, which improved policy rate management and supported more effective transmission to market rates by mitigating volatility in short-term interest rates. ${ }^{25}$ Specifically, the authorities placed limits on the volume of short-term open-market operations, while the CBI's certificates of deposits (CD) issuance strategy was adjusted, by lowering the maturity to 28-days (from 6 months) and having weekly auctions, with the total volume geared to absorb the estimated surplus liquidity. As a result, short-term market rates were brought within the CBI's rate corridor, which, together with the narrowing of the interest rate corridor from 500 bps to 300 bps at end-2009, provided a better signal of monetary policy stance. However, while excess reserves have declined, the CBI has not been able to anchor money market rates close to the center of the corridor and the money market remains dysfunctional.

\section{Capital controls have helped stabilize the currency. An important reason for} introducing capital controls was to avoid the damaging effect of the unwinding of carry trade. With capital controls, the large non-resident króna holdings in Iceland could not be quickly unloaded. This was crucial in avoiding the collapse of the currency, which would have otherwise had a devastating effect on the balance sheets of households and firms. Moreover, as capital controls restricted investment opportunity abroad, both foreign and local holders of offshore króna found it profitable to invest in government bonds, which facilitated the financing of budget deficit and helped avoid a sovereign financing crisis.

\section{The authorities have adopted a conditions-based two-stage strategy to eliminate} capital controls in the medium term. If maintained for a long period, capital controls could have some adverse side effects such as distorting portfolio allocation and discouraging the repatriation of export proceeds. To address this, the authorities developed Iceland-specific strategy of capital control liberalization with two stages: first liberalizing offshore króna holdings, and then onshore (largely resident) króna holding. Progress in meeting the conditions

\footnotetext{
${ }^{24}$ Work on the contours of a post-program monetary policy framework is underway. The financial crisis has exposed the difficulties of implementing monetary policy in a small open economy like Iceland that is subject to large shocks and volatile capital flows. The CBI has released a policy paper on the future of the monetary policy framework and the macro-prudential agenda in December 2010.

${ }^{25}$ TA by the IMF's Monetary and Capital Markets department has been instrumental in improving monetary operations.
} 
for capital account liberalization has been made in a few areas. In particular, a lot has been achieved in placing public finances on a sustainable path, the banking sector has been strengthened, and international reserves have risen, and sovereign market access has been regained. However, Iceland still faces a formidable task in lifting its capital controls and the pace of liberalization should take into account several factors (Figure 5). Specifically, offshore króna holdings which are still large and represent a considerable source of potential pressure on the currency and foreign reserves; potentially large pent up demand of residents to invest abroad; and finally, the banking system, which while in much better shape, remains vulnerable to both liquidity and balance sheet shocks.

\section{Conclusions And Lessons}

41. The Iceland program delivered its main objectives. First, the exchange rate has been stabilized. Following the sharp depreciation before and during the crisis, the króna stabilized at a competitive level, avoiding a further deterioration in private and public sector balance sheets, which would have had adverse impact on domestic demand. Capital controls were essential for stabilizing the currency, but the gradual improvement in investor confidence, supported by the successful issuance of the first post-crisis sovereign bond in mid-2011 and the orderly current account adjustment has allowed the authorities to begin gradually liberalizing the controls. Second, significant progress has been made in placing public finances on a sustainable track. In the midst of the deepest recession in Iceland's modern history, the authorities undertook an impressive consolidation program, as primary balance improved by 6 percent of GDP during 2009-11, putting the public debt ratio on a declining path. Third, the banking system was significantly downsized and now holds assets of about 200 percent of GDP (compared to around 900 percent of GDP pre-crisis), with substantial private sector involvement during the restructuring. Finally, household and corporate debt restructuring is advancing, which will help restore bank and private sector balance sheets.

\section{The program's design was instrumental in mitigating the risks, striking an} appropriate balance between short and medium term objectives. The initial phase of the program focused on stabilization. While exchange rate stabilization was a key goal, fiscal consolidation plans were delayed and automatic stabilizers allowed to operate fully, to avoid a deepening of the recession. In the second phase, the program's focus shifted to fiscal adjustment and bank restructuring. A consolidation program designed by the authorities to achieve sustainability, while preserving Iceland's welfare state, began in 2009. At the same time bank restructuring proceeded as envisaged under the program, despite some delays. Initial uncertainties about bank restructuring costs posed major risks to the program but were mitigated by the authorities' commitment and subsequent actions to limit their absorption by the public sector. The significant risk of large capital outflows was mitigated by focusing monetary and exchange rate policies on building confidence and imposing capital controls. Litigation risks arising from the Emergency Law have been significantly reduced by the Supreme Court ruling to uphold depositor priority, while Icesave risks, though smaller, are still present.

43. However, Iceland continues to face large risks and vulnerabilities in key areas which require further policy efforts. Specifically: 
- $\quad$ On fiscal front, while a lot has been achieved during the program in mitigating risks and putting public finances on a sustainable path, public debt remains large. Given the high level of public debt, fiscal consolidation efforts should continue to ensure that fiscal sustainability is secured.

- On capital account liberalization, Iceland faces significant challenges in lifting controls without reversing the stabilization gains. While keeping capital controls for too long could prolong distortions and result in resource misallocation, too quick a pace of liberalization or insufficient administrative controls during the liberalization process could lead to depletion of reserves and disorderly depreciation of the currency, destabilizing financial system.

- On financial sector, completion of the recapitalization of the core financial system has been a significant achievement in its restructuring, but more needs to be done to address remaining vulnerabilities. Notably, the still large NPLs need to be reduced further through private sector debt restructuring and financial imbalances should be handled through careful asset-liability management.

- On financial supervision, while major progress has been made, the remaining supervisory gaps indentified by the comprehensive assessment of Iceland's compliance with Basel Core Principles for Effective Supervision need to be addressed, in line with the action plan being prepared by the FME.

\section{The experience with the 2008 SBA for Iceland has highlighted key lessons for future} Fund engagement:

- $\quad$ Strong ownership is critical for a successful completion of Fund-supported programs, as found by other program reviews. For example, a key objective of the authorities was to implement a fiscal adjustment, while preserving Iceland's social model. While the Fund and the authorities had to agree on fiscal targets needed to ensure sustainability, the authorities took the initiative and designed the measures needed to achieve these targets but in a manner consistent with accomplishing their social objective, which created buy-in.

- In the context of Fund-supported programs, the social impact following a severe crisis can be alleviated by having cuts without compromising social benefits. Backed by revenue increase, this can help mitigate the burden on vulnerable groups and, together with an early involvement of social partners, foster broader ownership.

- $\quad$ An approach to bank restructuring that allowed creditors to take upside gains but also bear part of the initial costs helped limit the absorption of private sector losses by public sector.

- When all other options are exhausted or other policy instruments are not available, capital controls could be used on temporary basis and as a "last resort" tool for program crisis cases. In Iceland's context, capital controls were unavoidable, given the huge financial sector and the large foreign exchange exposures of the private sector, and helped avoid disorderly deleveraging. 


\section{APPENDIX I. COMMENTS AND VIEWS EXPRESSED BY ICELANDIC OFFICIALS AND \\ STAKEHOLDERS ${ }^{26}$}

\section{The authorities and stakeholders broadly agreed with the main findings of the EPE.}

Overall, they viewed the 2008 SBA as successfully achieving its key objectives, namely to:

(i) stabilize the exchange rate; (ii) put public finances on a path to achieving sustainability; and (iii) restructure the banking, while limiting the absorption of banking crisis costs by the public sector. The authorities and stakeholders appreciated the Fund's flexibility in key aspects of the program design and implementation (e.g. the design and time profile of fiscal consolidation), which were instrumental in encouraging buy-in and ownership. Also, the Fund's technical assistance, notably on fiscal matters, was considered particularly useful.

\section{While recognizing that monetary policy contributed to the imbalances prior to the crisis,} they noted that loose fiscal policy complicated monetary policy making. Icelandic officials noted that monetary policy partly contributed to the carry trade in the run-up to the 2008 crisis. However, they also pointed out that fiscal policy was too lax and put an excessive burden on monetary policy, while heavy FDI and other capital inflows further complicated monetary policy conduct. Thus, the authorities and stakeholders saw the need for more instruments, in particular, macroprudential tools to deal with capital flows in a small open economy such as Iceland. Regarding monetary policy stance during the SBA arrangement, several officials were of the view that interest rates at the beginning of the SBA arrangement were set at exceptionally high levels, increasing the burden on the highly indebted private sector and stifling the recovery.

\section{The authorities and stakeholders noted that home-grown supervision and regulation issues} contributed to the large financial imbalances, but argued that faults at the EU level also played a role. The Icelandic officials acknowledged that there were shortcomings in Iceland in the run up to the crisis that allowed the rapid expansion of balance sheets of Icelandic banks. In particular, there was a supervision failure to allow lending to bank shareholders for equity buybacks. However, they also emphasized that there were supervisory and regulatory failures at the EU level. In particular, they saw as the main fault line the contradiction between, on the one hand, the area-wide permission to operate based on home licensing and a common regulatory framework (the European passport) and, on the other hand, national supervision, a national safety net of deposit insurance and lender of last resort (LOLR) and national crisis management and resolution regimes. Icelandic officials pointed out that against that background, there were no legal tools at their disposal that allowed them to deal with Icesave, without breaching the European passport. Regarding streamlining supervisory arrangements going forward, Icelandic officials noted that, while there may be some gains of economy of scale, improvement of information exchange among institutions is crucial.

\footnotetext{
${ }^{26}$ The Appendix summarizes comments and views expressed during a staff visit to Reykjavik on December 13-16, 2011 by present and former high-ranking officials from key institutions in Iceland (the authorities and stakeholders, or the Icelandic officials, which is used in the text for brevity) that were involved in the 2008 SBA arrangement.
} 
They pointed out that, while the banking system and supervision have been strengthened, further action is needed on both fronts. They pointed out that the banking system was downsized significantly, the recapitalization of the core banks was completed, and on- and offsite supervision was strengthened. Looking forward, the authorities and stakeholders saw the need to speed up the restructuring of nonperforming loans, to further strengthen balance sheets of the banks, which currently operate in a protected environment, given capital controls. The Icelandic officials noted that steps are taken to strengthen analytical capability of supervision and emphasized that providing adequate resources for FME and maintaining its independence are important. Regarding streamlining financial architecture going forward, the authorities and stakeholders recognized that there may be some economy of scale gains, but saw as critical efficient and timely exchange of information between various institutions under the current arrangement.

The authorities and stakeholders noted that there was broad agreement on the need to introduce capital controls at the start of the SBA and recognized the risks of their quick liberalization. Icelandic officials acknowledged that capital controls have secured liquidity for the banks and facilitated financing of the budget. However, they pointed out that keeping capital controls for long would distort resource allocation and inflict long-term costs to the Icelandic economy. Accordingly, there was broad agreement that a balanced state-dependent approach is needed in liberalizing capital controls, with the pace of lifting the controls depending on whether specific conditions were fulfilled. In particular, achieving macroeconomic stabilization, including the implementation of a credible plan for fiscal sustainability and declining inflation, a sound financial system, and, an adequate level of foreign exchange reserves.

The Icelandic officials recognized that, while a lot has been achieved under the SBA, there are significant risks going forward that require further policy action. Over the medium term, the authorities and stakeholders saw capital control liberalization, private sector debt restructuring, and ensuring that public finances are put on a sustainable path as posing key challenges and risks. Regarding fiscal risks, the Icelandic officials pointed to the link with capital control liberalization and viewed the implementation of the medium-term fiscal framework as a way of achieving sustainability. Also, the Icelandic officials emphasized the importance of maintaining the recovery momentum over the short term, while boosting growth potential over the medium term by addressing underlying structural issues, including by raising productivity. 
Table 1. Iceland: Selected Economic Indicators, 2005-12

\begin{tabular}{|c|c|c|c|c|c|c|c|c|}
\hline & 2005 & 2006 & 2007 & 2008 & 2009 & 2010 & $\begin{array}{c}2011 \\
\text { Est. }\end{array}$ & $\begin{array}{l}2012 \\
\text { Proj. }\end{array}$ \\
\hline & \multicolumn{8}{|c|}{ (Percentage change, unless otherwise indicated) } \\
\hline \multicolumn{9}{|l|}{ National Accounts (constant prices) } \\
\hline Gross domestic product & 7.2 & 4.7 & 6.0 & 1.3 & -6.8 & -4.0 & 3.1 & 2.4 \\
\hline Total domestic demand & 15.5 & 9.1 & 0.0 & -8.6 & -20.3 & -2.3 & 3.9 & 3.7 \\
\hline Private consumption & 12.7 & 3.6 & 5.7 & -7.9 & -14.9 & -0.4 & 4.0 & 3.0 \\
\hline Public consumption & 3.5 & 4.0 & 4.1 & 4.6 & -1.7 & -3.4 & -0.6 & -0.4 \\
\hline Gross fixed investment & 34.4 & 24.4 & -12.2 & -20.0 & -51.6 & -8.1 & 13.4 & 13.8 \\
\hline Export of goods and services & 7.5 & -4.6 & 17.7 & 7.0 & 6.6 & 0.4 & 3.2 & 2.9 \\
\hline Imports of goods and services & 29.3 & 11.3 & -1.5 & -18.4 & -24.0 & 4.0 & 6.3 & 5.1 \\
\hline Output gap $1 /$ & 2.8 & 2.0 & 3.6 & 2.2 & -1.9 & -4.5 & -1.0 & -0.7 \\
\hline \multicolumn{9}{|l|}{ Selected Indicators } \\
\hline Nominal GDP (bln ISK) & $1,025.7$ & $1,168.6$ & $1,308.5$ & $1,482.0$ & $1,495.4$ & $1,534.2$ & $1,630.2$ & $1,732.5$ \\
\hline Unemployment rate $2 /$ & 2.1 & 1.3 & 1.0 & 1.6 & 8.0 & 8.1 & 7.4 & 6.3 \\
\hline Consumer price index & 4.0 & 6.8 & 5.0 & 12.4 & 12.0 & 5.4 & 4.0 & 4.8 \\
\hline Nominal wage index & 6.5 & 9.1 & 9.3 & 4.0 & 0.5 & 3.1 & 5.7 & 6.0 \\
\hline Nominal effective exchange rate $3 /$ & 10.2 & -11.8 & 2.5 & -40.4 & -34.2 & 2.9 & -0.1 & -3.6 \\
\hline Real effective exchange rate $3 /$ & 13.3 & -7.1 & 5.1 & -20.7 & -18.4 & 6.4 & 0.9 & -0.5 \\
\hline Terms of trade & 0.9 & 3.4 & 0.2 & -9.3 & -6.7 & 6.1 & -1.8 & -0.7 \\
\hline \multicolumn{9}{|l|}{ Money and Credit } \\
\hline Base Money & 32.2 & 27.9 & 190.7 & -31.5 & 1.3 & -19.4 & -20.7 & $\ldots$ \\
\hline Deposit money bank credit (end-period) & 76.0 & 44.4 & 56.6 & -28.3 & -17.8 & -3.4 & 3.2 & $\ldots$ \\
\hline of which to residents (end-period) & 54.7 & 33.6 & 28.3 & $\ldots$ & $\ldots$ & $\ldots$ & $\ldots$ & $\ldots$ \\
\hline Broad money (end-period) & 23.2 & 19.6 & 56.4 & 36.3 & 1.0 & -10.0 & 7.2 & $\ldots$ \\
\hline $\mathrm{CBI}$ policy rate (period average) $4 /$ & 10.5 & 14.1 & 13.8 & 15.4 & 13.7 & 7.8 & 4.4 & $\ldots$ \\
\hline & \multicolumn{8}{|c|}{ (Percent of GDP, unless otherwise indicated) } \\
\hline \multicolumn{9}{|l|}{ Public Finance } \\
\hline \multicolumn{9}{|l|}{ General government 5/ } \\
\hline Revenue & 47.1 & 48.0 & 47.7 & 44.1 & 41.1 & 41.5 & 41.7 & 41.8 \\
\hline Expenditure & 42.2 & 41.6 & 42.3 & 44.6 & 49.7 & 47.9 & 46.3 & 44.6 \\
\hline Balance & 4.9 & 6.3 & 5.4 & -0.5 & -8.6 & -6.4 & -4.6 & -2.8 \\
\hline Primary balance & 6.1 & 6.7 & 5.7 & -0.5 & -6.5 & -2.7 & -1.1 & 1.3 \\
\hline \multicolumn{9}{|l|}{ Balance of Payments } \\
\hline Current account balance & -16.1 & -25.6 & -15.7 & -28.4 & -11.8 & -8.4 & -6.5 & -2.8 \\
\hline Trade balance & -12.2 & -17.5 & -10.1 & -2.3 & 8.4 & 10.1 & 8.2 & 6.6 \\
\hline Financial and capital account & 14.0 & 43.3 & 18.1 & -66.9 & -28.2 & 52.9 & 15.3 & -1.4 \\
\hline Net errors and omissions & 2.6 & -11.0 & -1.0 & -19.5 & 37.3 & -37.7 & -2.8 & 0.0 \\
\hline Gross external debt $6 /$ & 284.5 & 433.5 & 605.9 & 564.7 & 266.5 & 289.7 & 250.4 & 204.2 \\
\hline Central bank reserves (US $\$$ billion) & 1.1 & 2.3 & 2.6 & 3.6 & 3.9 & 5.8 & 8.7 & 7.3 \\
\hline
\end{tabular}

Sources: Statistics Iceland; Central Bank of Iceland; Ministry of Finance; and IMF staff estimates.

1 Staff estimates. Actual minus potential output, in percent of potential output.

2/ In percent of labor force.

3/ A positive (negative) sign indicates an appreciation (depreciation).

4/ Data prior to 2007 refers to annual rate of return. 2007 and on, refers to nominal interest rate.

$5 /$ National accounts basis.

6/ Including face value of old banks debt before 2009. Related interest transactions are not included from Q4 2008 on. 
Table 2. Iceland: Medium-Term Projections, 2009-17

\begin{tabular}{|c|c|c|c|c|c|c|c|c|c|}
\hline \multirow[t]{3}{*}{ 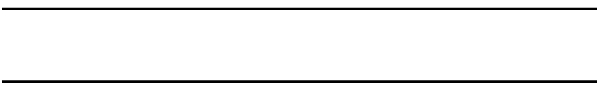 } & \multirow{2}{*}{2009} & \multirow{2}{*}{2010} & 2011 & 2012 & 2013 & \multirow{2}{*}{$\begin{array}{l}2014 \\
\text { Proj. }\end{array}$} & \multirow{2}{*}{$\begin{array}{l}2015 \\
\text { Proj. }\end{array}$} & \multirow{2}{*}{$\begin{array}{l}2016 \\
\text { Proj. }\end{array}$} & \multirow{2}{*}{$\begin{array}{l}2017 \\
\text { Proj. }\end{array}$} \\
\hline & & & Est. & Proj. & Proj. & & & & \\
\hline & \multicolumn{9}{|c|}{ (Percentage change) } \\
\hline \multicolumn{10}{|l|}{ Real economy } \\
\hline Real GDP & -6.8 & -4.0 & 3.1 & 2.4 & 2.6 & 2.2 & 2.6 & 2.7 & 2.9 \\
\hline Real domestic demand & -20.3 & -2.3 & 3.9 & 3.7 & 3.4 & 2.9 & 1.6 & 2.5 & 3.0 \\
\hline Private consumption & -14.9 & -0.4 & 4.0 & 3.0 & 3.2 & 3.2 & 3.2 & 3.1 & 3.0 \\
\hline Public consumption & -1.7 & -3.4 & -0.6 & -0.4 & -0.6 & -0.1 & 0.4 & 0.2 & 1.8 \\
\hline Gross fixed investment & -51.6 & -8.1 & 13.4 & 13.8 & 10.7 & 6.3 & -2.1 & 3.6 & 4.4 \\
\hline Net exports $1 /$ & 11.7 & -1.1 & -0.7 & -0.4 & -0.2 & -0.1 & 1.0 & 0.5 & 0.3 \\
\hline Exports of goods and services & 6.6 & 0.4 & 3.2 & 2.9 & 2.9 & 2.9 & 4.0 & 3.8 & 3.6 \\
\hline Imports of goods and services & -24.0 & 4.0 & 6.3 & 5.1 & 4.2 & 4.0 & 2.4 & 3.5 & 3.9 \\
\hline Output gap 2/ & -1.9 & -4.5 & -1.0 & -0.7 & 0.0 & 0.0 & 0.0 & 0.0 & 0.0 \\
\hline Potential output & -2.8 & -1.5 & -0.1 & 1.6 & 1.8 & 2.2 & 2.6 & 2.7 & 2.9 \\
\hline Unemployment rate $3 /$ & 8.0 & 8.1 & 7.4 & 6.3 & 6.0 & 5.0 & 4.4 & 4.0 & 4.0 \\
\hline Real wages & -10.3 & -2.2 & 1.6 & 1.2 & 1.4 & 2.2 & 2.1 & 2.1 & 2.1 \\
\hline $\mathrm{CPI}$ inflation & 12.0 & 5.4 & 4.0 & 4.8 & 3.5 & 2.5 & 2.5 & 2.5 & 2.5 \\
\hline CPI inflation (excl. effect of ind. taxes) & 11.4 & 4.4 & 3.8 & 4.6 & 3.5 & 2.5 & 2.5 & 2.5 & 2.5 \\
\hline CPI inflation (end of period) & 7.5 & 2.4 & 5.5 & 4.1 & 2.9 & 2.4 & 2.5 & 2.5 & 2.5 \\
\hline Nominal ISK/EUR exchange rate & 172.0 & 161.7 & 161.0 & 162.9 & 165.9 & 167.6 & 168.5 & 168.7 & 168.7 \\
\hline Real exchange rate (+ appreciation) & -18.4 & 6.4 & 0.9 & -0.5 & -0.5 & -0.5 & 0.0 & 0.0 & 0.0 \\
\hline Terms of trade & -6.7 & 6.1 & -1.8 & -0.7 & 1.1 & -0.3 & 0.0 & -0.1 & 0.0 \\
\hline Nominal GDP (bln ISK) & 1495.4 & 1534.2 & 1630.2 & 1732.5 & 1853.4 & 1941.7 & 2043.5 & 2149.2 & 2266.0 \\
\hline & \multicolumn{9}{|c|}{ (Percent of GDP, unless otherwise indicated) } \\
\hline \multicolumn{10}{|l|}{ Balance of Payments } \\
\hline Current account & -11.8 & -8.4 & -6.5 & -2.8 & -1.9 & -3.0 & -3.0 & -3.6 & -2.1 \\
\hline Underlying current account 4 / & 8.7 & 13.1 & 5.6 & 2.3 & 3.1 & 2.1 & 2.1 & 1.5 & 2.9 \\
\hline Trade balance & 8.4 & 10.1 & 8.2 & 6.6 & 6.6 & 6.0 & 7.0 & 7.1 & 7.0 \\
\hline Net income balance 5/ & -19.6 & -17.9 & -14.2 & -8.9 & -8.1 & -8.5 & -9.5 & -10.3 & -8.7 \\
\hline Capital and financial account & -28.2 & 52.9 & 15.3 & -1.4 & -13.0 & -1.3 & 3.8 & -6.3 & 2.4 \\
\hline Capital transfer, net & -0.1 & -0.1 & -0.1 & 0.0 & 0.0 & 0.0 & 0.0 & 0.0 & 0.0 \\
\hline Direct investment, net & -18.3 & 21.8 & 7.9 & 5.1 & 5.0 & 5.5 & 4.0 & 4.0 & 5.3 \\
\hline Portfolio investment, net & 3.1 & -4.4 & -5.6 & 100.8 & -32.6 & -19.7 & -15.3 & -6.5 & -5.2 \\
\hline Other investment, net $6 /$ & -13.0 & 35.5 & 13.1 & -107.3 & 14.5 & 13.0 & 15.1 & -3.7 & 2.3 \\
\hline Accumulation of arrears & 0.0 & 0.0 & 0.0 & 0.0 & 0.0 & 0.0 & 0.0 & 0.0 & 0.0 \\
\hline Extraordinary financing & 5.5 & 8.3 & 14.6 & -6.1 & -0.9 & -2.3 & -3.3 & -1.7 & 0.0 \\
\hline Gross external debt $7 /$ & 266.5 & 289.7 & 250.4 & 204.2 & 178.3 & 167.2 & 157.2 & 147.3 & 140.7 \\
\hline Underlying gross external debt 8 / & 262.2 & 271.3 & 224.5 & 188.2 & 169.8 & 165.2 & 157.2 & 147.3 & 140.7 \\
\hline Net external debt $9 /$ & 160.4 & 181.9 & 146.6 & 186.7 & 138.5 & 111.4 & 89.0 & 71.4 & 64.9 \\
\hline Central bank reserves (US $\$$ billion) & 3.9 & 5.8 & 8.7 & 7.3 & 5.0 & 4.1 & 3.7 & 1.8 & 1.8 \\
\hline \multicolumn{10}{|l|}{ General government accounts } \\
\hline Revenue & 41.1 & 41.5 & 41.7 & 41.8 & 41.2 & 41.6 & 41.6 & 41.3 & 41.1 \\
\hline Expenditure & 49.7 & 47.9 & 46.3 & 44.6 & 43.1 & 42.3 & 41.2 & 40.6 & 40.2 \\
\hline Overall balance & -8.6 & -6.4 & -4.6 & -2.8 & -1.9 & -0.7 & 0.4 & 0.7 & 1.0 \\
\hline Primary balance & -6.5 & -2.7 & -1.1 & 1.3 & 2.3 & 3.4 & 4.3 & 4.5 & 4.5 \\
\hline Primary balance (excl. new road projects) & -6.5 & -2.7 & -1.1 & 1.4 & 2.4 & 3.6 & 4.3 & 4.5 & 4.5 \\
\hline Change in primary balance (excl. new road projects) & -6.0 & 3.8 & 1.6 & 2.5 & 1.0 & 1.1 & 0.7 & 0.2 & 0.0 \\
\hline Gross debt & 88.2 & 92.8 & 99.2 & 97.3 & 92.5 & 91.0 & 88.1 & 83.4 & 82.2 \\
\hline Net Debt & 55.8 & 62.8 & 64.6 & 66.4 & 64.7 & 63.1 & 60.2 & 57.1 & 53.6 \\
\hline
\end{tabular}

Sources: $\mathrm{CBI}$; and IMF staff estimates.

$1 /$ Contributions to grow th.

2/ In percent of potential output

$3 /$ In percent of labor force.

4/ Excludes old banks transactions. Since 2009 also excludes accrued interest payments on intra-company debt held by a large multinational.

$5 /$ Includes interest payments due from the financial sector and income receipts to the financial sector.

6/ Including face value of old banks debt before 2009. Related interest transactions are not included from Q4 2008 on.

7/ Including old banks before 2009. Old banks' total liabilities are excluded starting from 2009, but external debt includes TIF's deposit liabilities, and accumulated recovered assets from both external and domestic sources before being paid out to foreign creditors. Once recovered, these assets are recorded as short-term debt.

8/ Excluding short-term debt that are covered by external assets.

9/ Gross external debt minus debt securities and other investment assets. 
Table 3. Iceland: Quantitative Performance Criteria and Indicative Targets $1 /$

\begin{tabular}{|c|c|c|c|c|c|c|c|c|c|c|c|c|c|c|}
\hline & \multicolumn{2}{|c|}{ October 2009} & \multicolumn{2}{|c|}{ December 2009} & \multicolumn{2}{|c|}{ May 2010} & \multicolumn{2}{|c|}{ September 2010} & \multicolumn{2}{|c|}{ December 2010} & \multicolumn{2}{|c|}{ March 2011} & \multicolumn{2}{|c|}{ March 2011} \\
\hline & Prog. & Actual & Prog. & Actual & Prog. & Actual & Prog. & Actual & Prog. & Actual & Prog. & Actual & Prog. & Actual \\
\hline \multicolumn{15}{|c|}{ (In billions of Króna) } \\
\hline $\begin{array}{l}\text { Floor on the change in the central government net } \\
\text { financial balance } 2 /\end{array}$ & -175 & -139.5 & -200 & -166.7 & -55 & -48.4 & -140 & -82.9 & -150 & -121 & -40 & -11.9 & -80 & -55.4 \\
\hline $\begin{array}{l}\text { Ceiling on the change in net domestic assets of the } \\
\text { Central Bank of Iceland 3/ }\end{array}$ & 20 & 34 & 42.6 & 30.3 & 65 & 16.3 & 40 & 1.1 & 40 & -15 & 35 & -29 & 13.5 & -40 \\
\hline $\begin{array}{l}\text { Ceiling on the change in the net domestic claims } \\
\text { of the Central Bank of Iceland to the central } \\
\text { government (indicative targets) }\end{array}$ & 70 & 8.6 & 70 & 13.8 & 80 & 19.5 & 80 & 9.6 & 80 & 41.6 & 70 & -14 & 70 & -7 \\
\hline
\end{tabular}

(In millions of U.S. dollars)

Floor on the change in net international reserves

of the Central Bank of Iceland 4/

$\begin{array}{lllllll}-425 & -278 & -475 & -319 & -325 & -122.9 & -530\end{array}$

Ceiling on the level of contracting or guaranteeing

of new medium- and long-term external debt by

central government $5 /$

Ceiling on the stock of central government short-

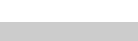

3500

term external debt 6/

1400

Ceiling on the accumulation of new external

payments arrears on external debt contracted or

guaranteed by central government from

multilateral or bilateral official creditors $6 /$

$1 /$ Cumulatively from the beginning of each year (unless otherwise indicated).

$2 /$ The net financial balance excludes the capital injection cost of bank and central bank recapitalization and excludes the increase in debt from guaranteeing the repayment of depositors in foreign branches of Icelandic banks, as well as the increase in central government debt due to on lending to finance road construction related to the Suðurlandsvegur, Vesturlandsvegur, Vadlaheidargong, and Reykjanesbraut road projects (the latter up to a maximum of ISK 6 billion).

3 / Excluding changes due to central bank recapitalization bond.

4/ (-) indicates decrease. NIR is defined as the difference of gross foreign assets and foreign liabilities (including all foreign currency deposits and other liabilities of financial institutions and the general government at the CBI; from September 2010, the definition excludes foreign currency deposits of the general government at the CBI, as specified in the TMU. NIR adjuster is specified in the TMU.

5/ Excludes IMF and excludes official bilateral loans for deposit insurance. Short term external debt has an original maturity of up to and including one year. Medium and long-term external debt has an original maturity of more than one year.

6/ Applies on a continuous basis. 
Figure 1. Iceland Program Projections and Outcomes 2008-2011 1/
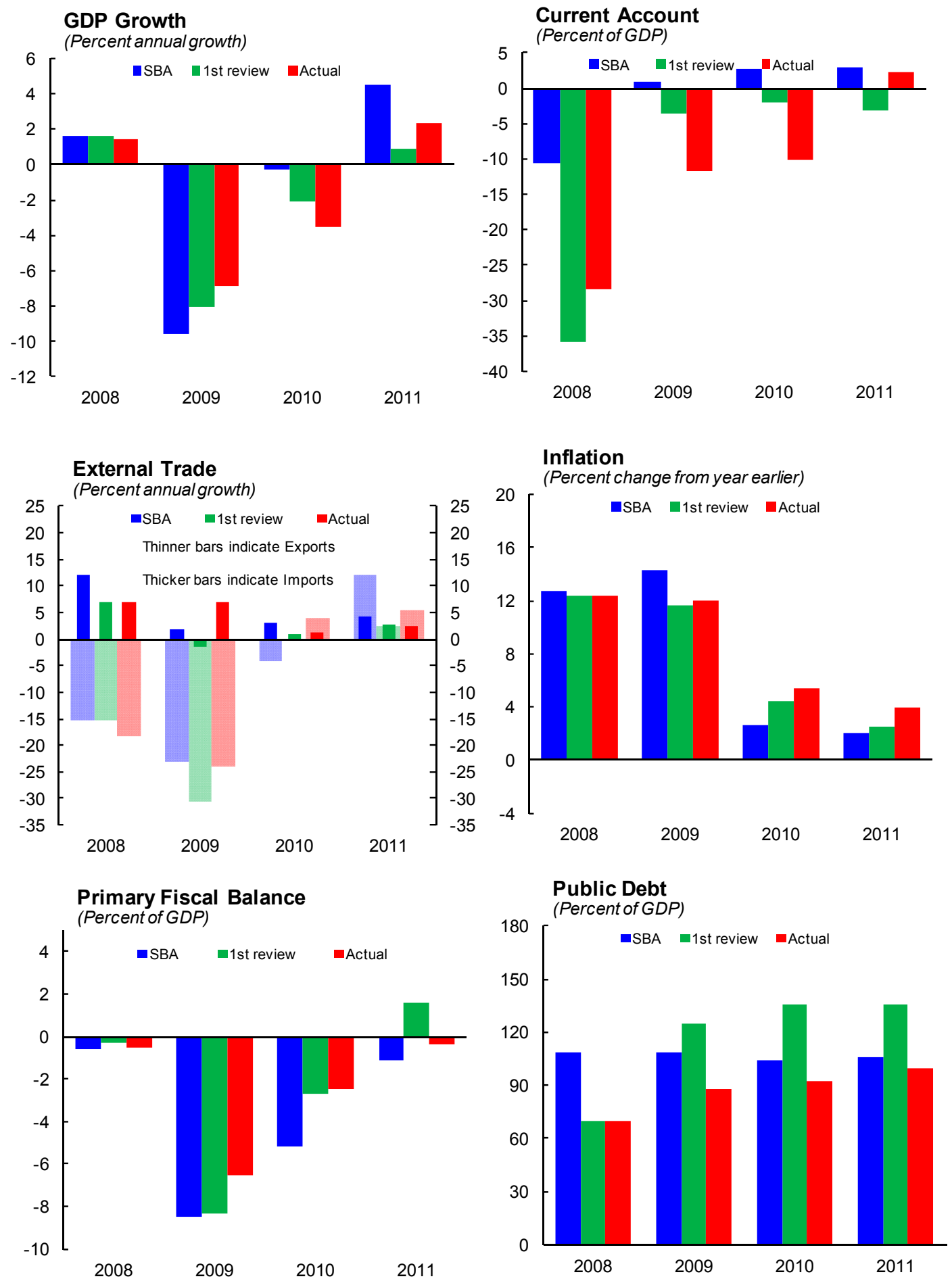

Sources: IceStat, Ministry of Finance, and IMF staff estimates.

1/ Numbers for 2011 are estimates. 
Figure 2. Loan Portfolio Restructuring: An Accelerating Process in 2011

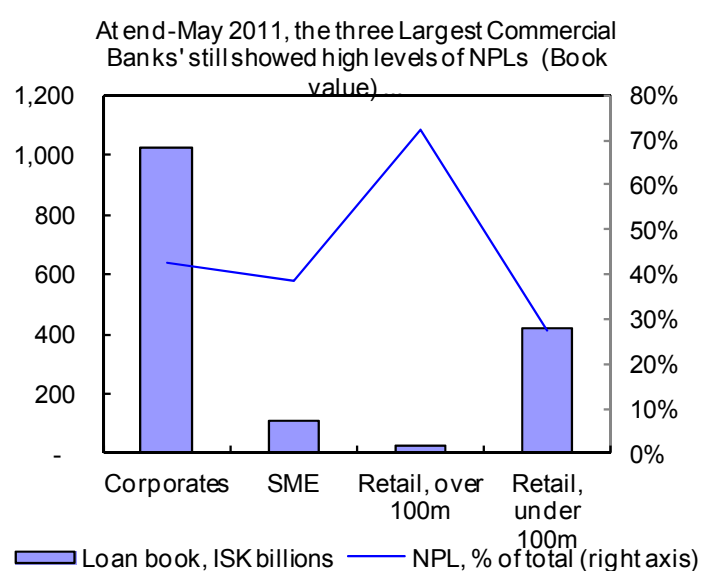

In 2011 the three largest banks accelerated their restructuring of corporate and SME loans ...

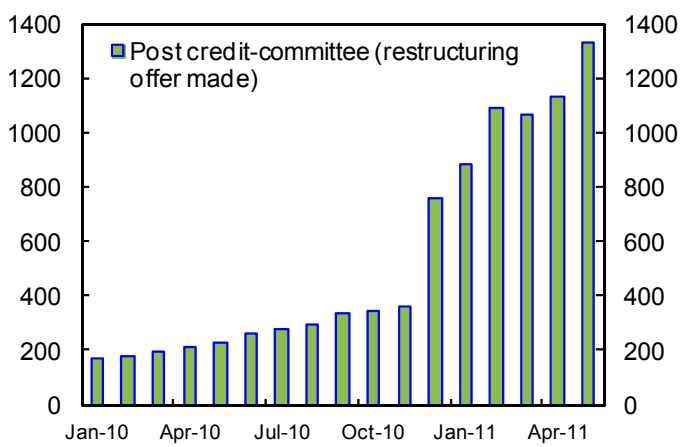

By mid-2011, the mortgages of 3030 households have been written down to 110 pct LTV un der the December 2010 sector agreement or un der previous debt relief arrangements...

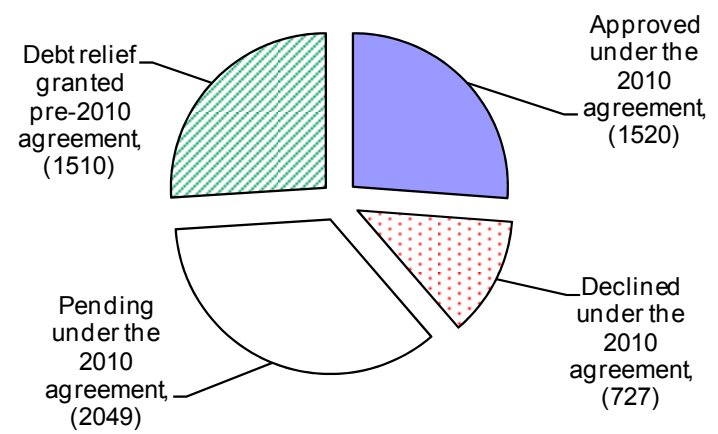

...but three quarters of these have been transferred to restructuring (workout) or legal collection procedures.

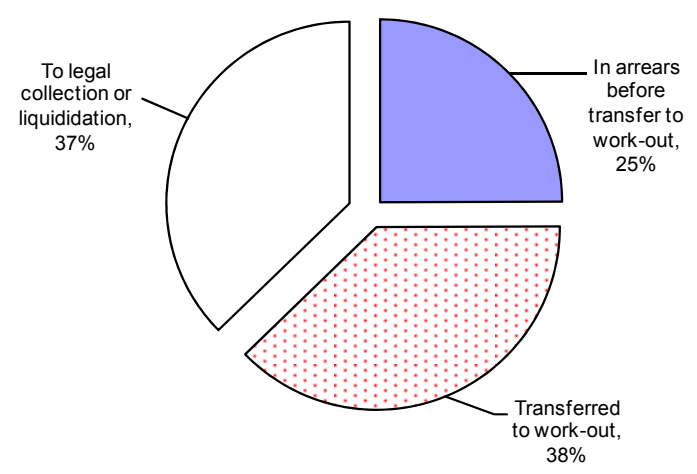

....including un der the simplified rules for SMEs ad opted by the industry.

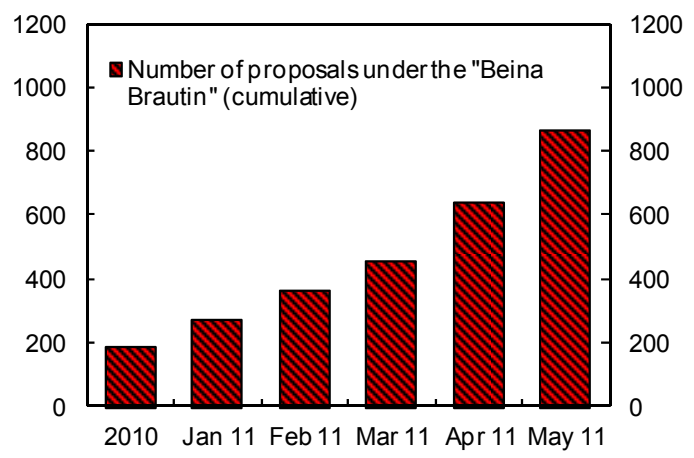

....and additional 2,400 households have received debt relief via rescheduling and write downs un der voluntary and court admin istrated debt mitigation.

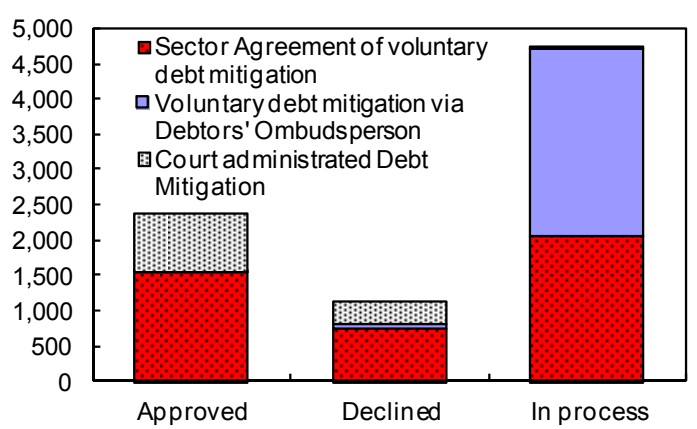

Source: Commercial Banks, debt restructuring monitoring committee, Debt Ombudsman Office. 
Figure 3: Monetary Policy Operations and Liquidity Management
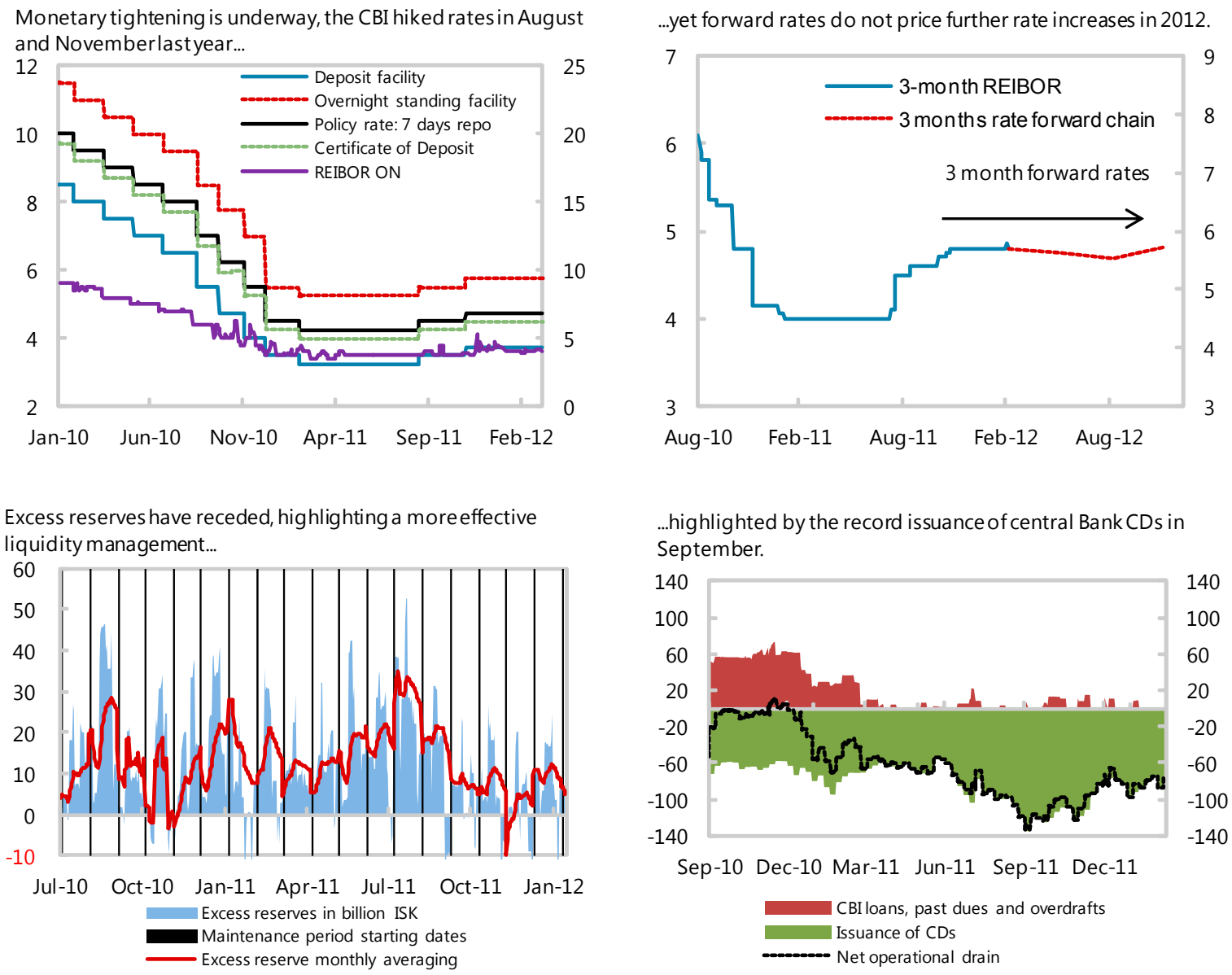

The asset side of the CBI balance sheet shows a substantial increase in gross FX reserves following the completion of the IMF program and the drawing of the last tranche of the Nordic loan.

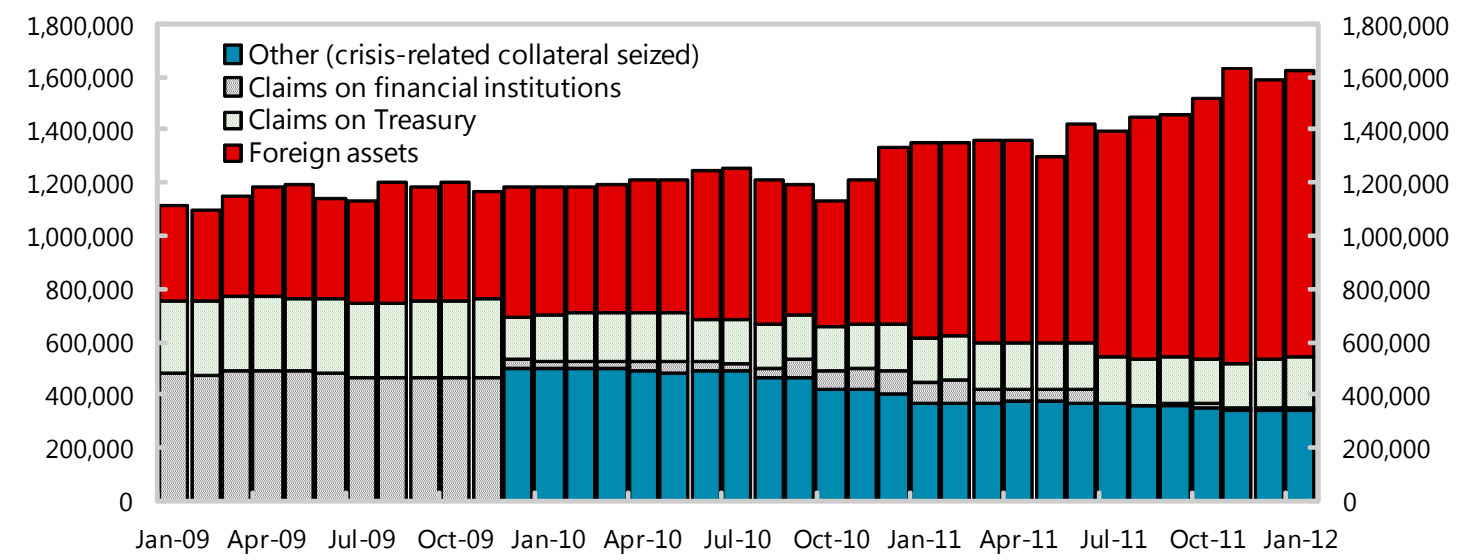

Sources: Central Bank of Iceland; and IMF staff calculations. 
Figure 4. Iceland: Price and Exchange Rate Developments

Inflation remains above the 2.5 per cent Central Bank's target...

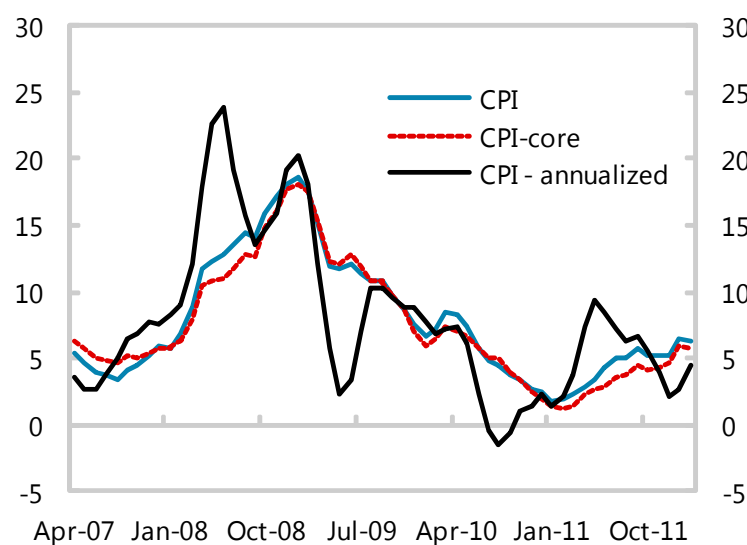

Pass-through from higher commodity prices and wage remain a concern..

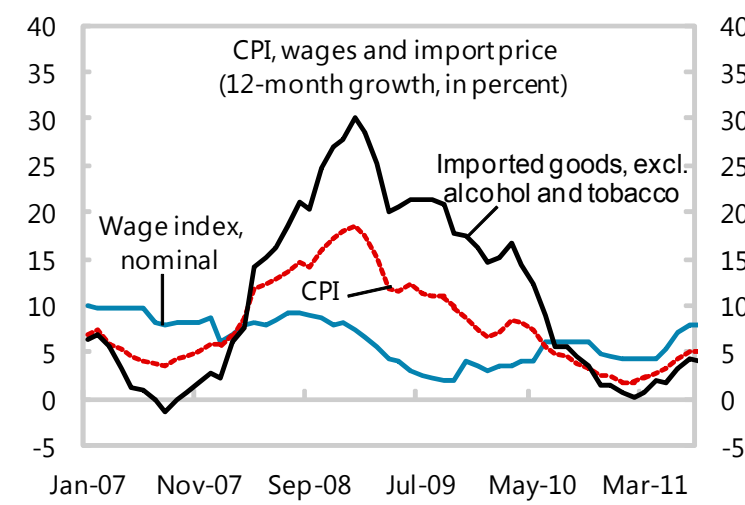

CBI FX purchases have continued at a steady pace following a large one-off purchase in December...

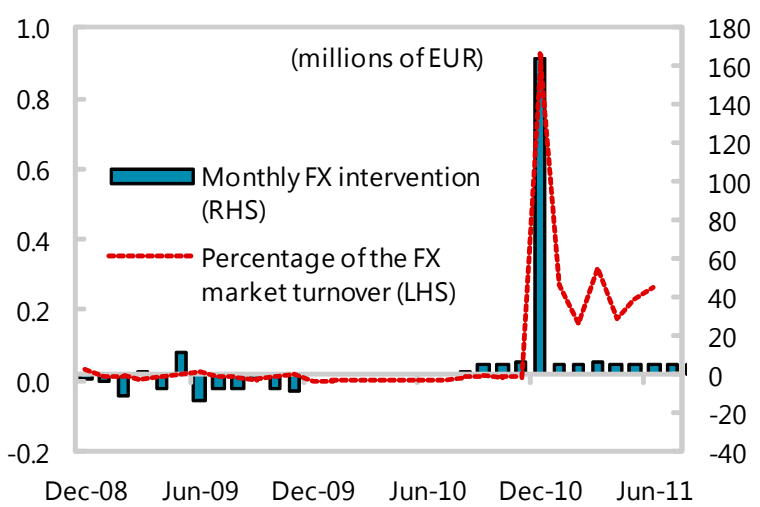

...and survey indicators and breakeven inflation remain high.

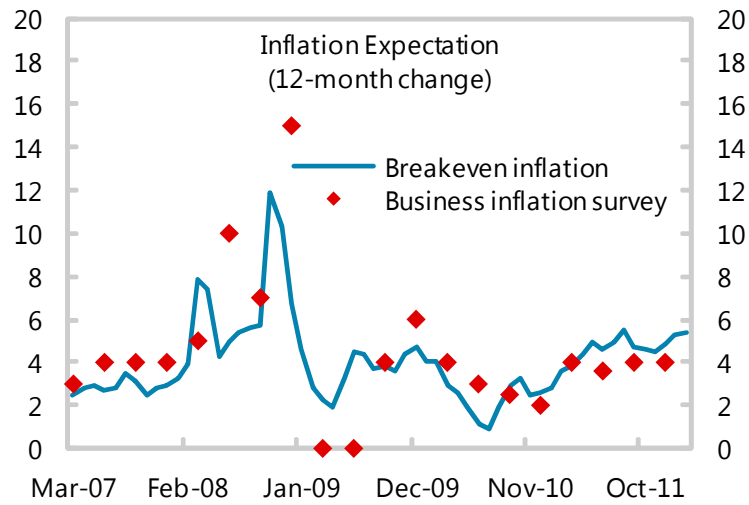

...given the recent weakening of the krona.

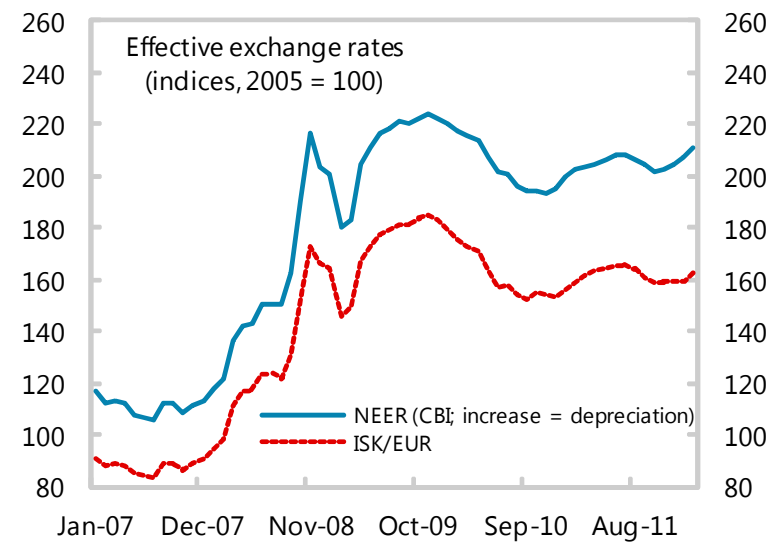

....and the real value of the krona has remained broadly stable.

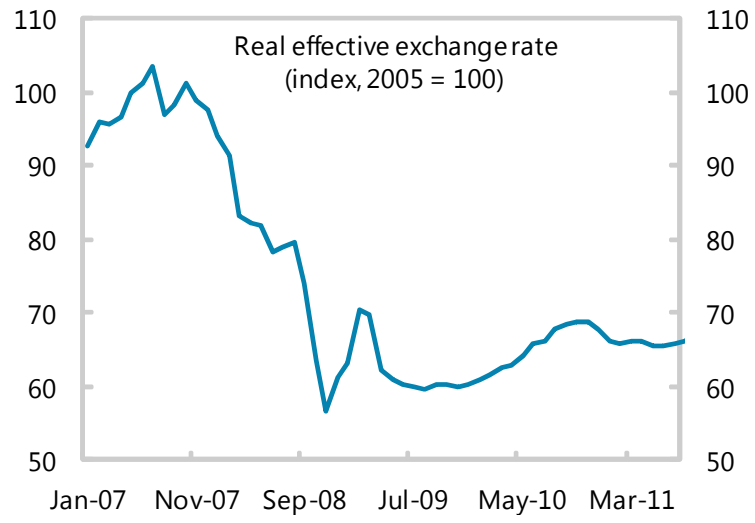

Sources: Central Bank of Iceland; and IMF's International Financial Statistics. 
Figure 5. Iceland: Capital Control Liberalization Challenges

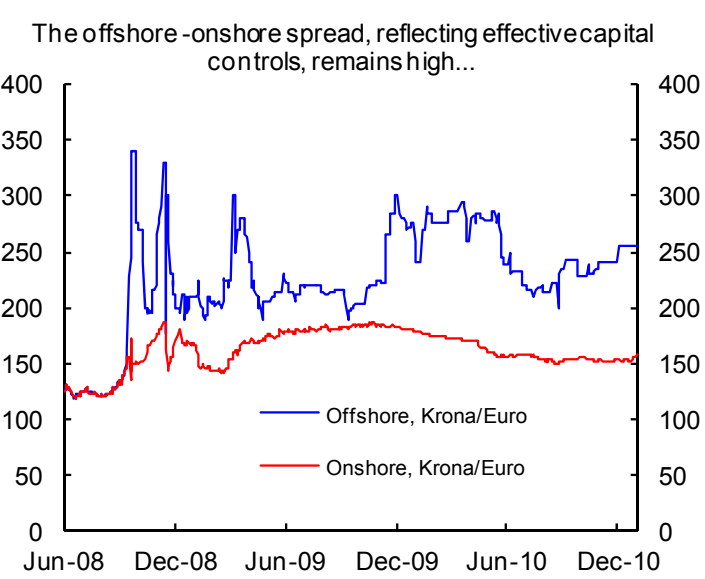

...with non-residents holding nearly 50 per cent of the stock of T-Bills...

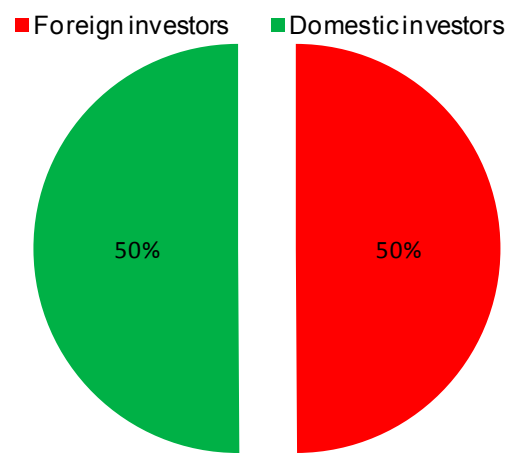

The release of offshore krona holdings may create pressure on sovereign and bankfunding...

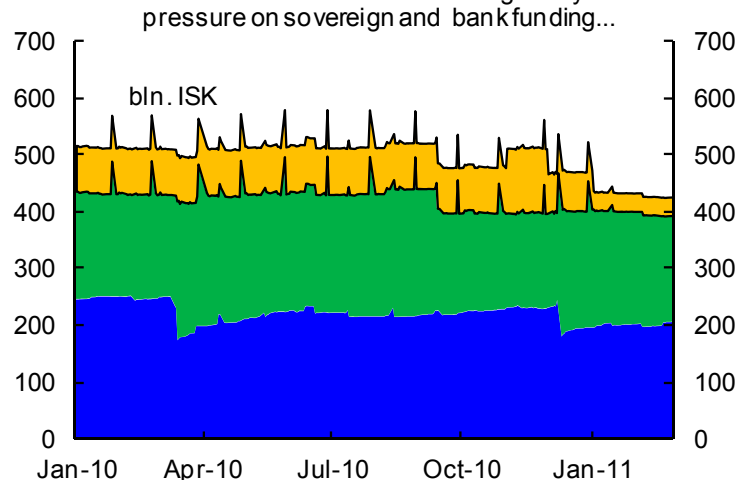

agovernment securities (bills plus bonds) held by non-residents

"offshore ISK Deposits (with commercial banks "vostro Accounts" and with the CBI for euroclear/clearstream)

口HFF bonds held by non-residents

Sources: Bloomberg; Central Bank of Iceland; and Datastream.

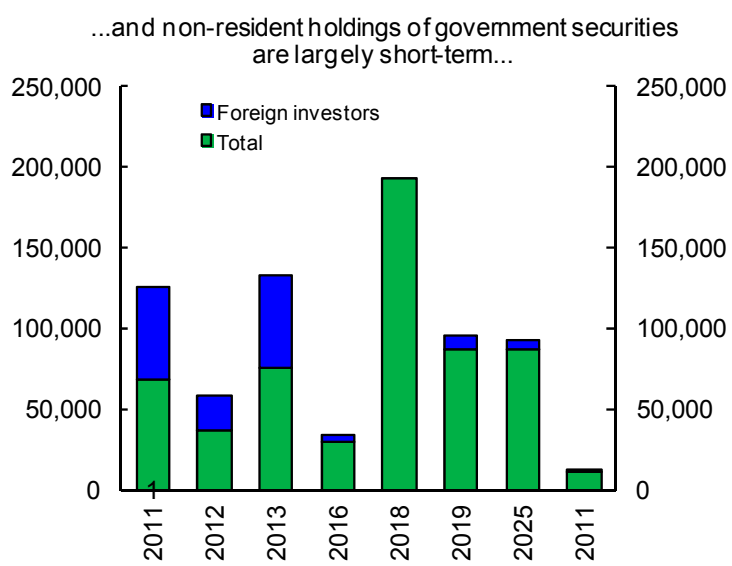
...but a much smaller proportion of the stock of bonds.

-Foreign investors $\square$ Domestic Investors
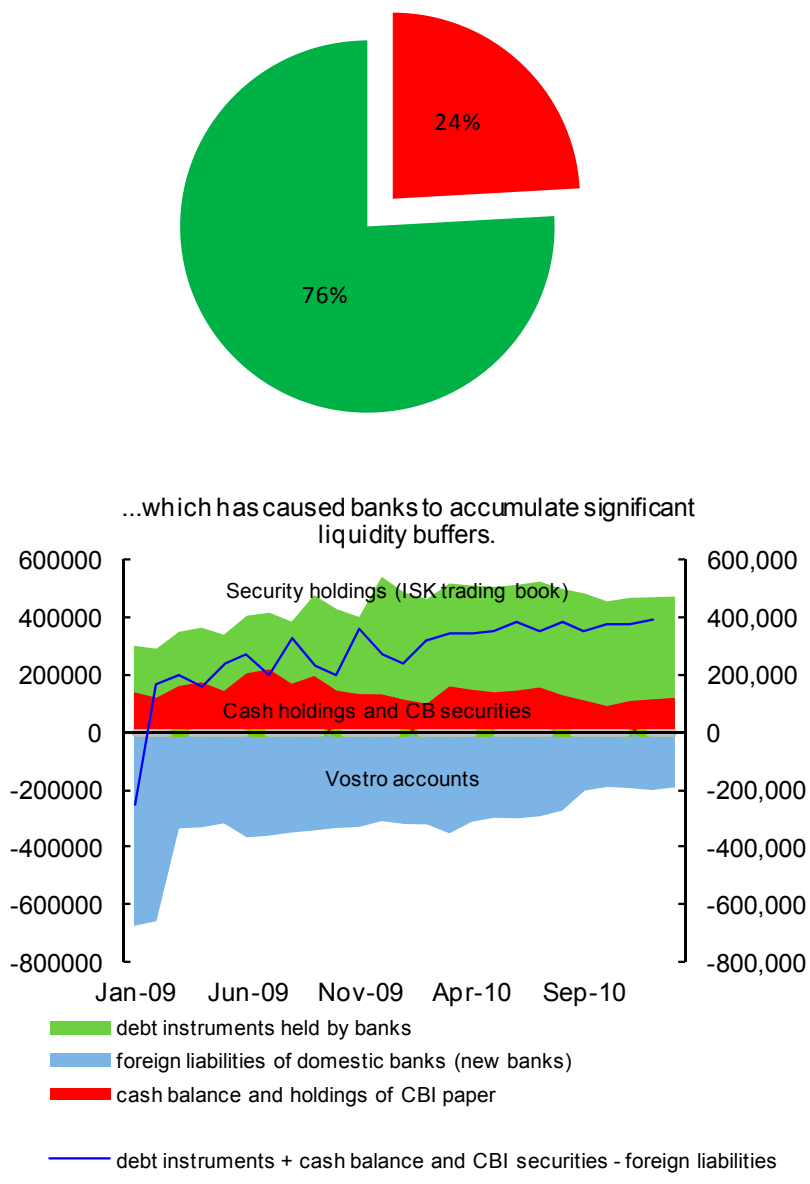